\title{
Effects of molecular weight and temperature on liquid-liquid phase separation in particles containing organic species and inorganic salts
}

\author{
Y. You and A. K. Bertram \\ Department of Chemistry, University of British Columbia, 2036 Main Mall, \\ Vancouver, BC, V6T 1Z1, Canada \\ Correspondence to: A. K. Bertram (bertram@chem.ubc.ca) \\ Received: 16 August 2014 - Published in Atmos. Chem. Phys. Discuss.: 10 September 2014 \\ Revised: 18 December 2014 - Accepted: 12 January 2015 - Published: 9 February 2015
}

\begin{abstract}
Atmospheric particles containing organic species and inorganic salts may undergo liquid-liquid phase separation when the relative humidity varies between high and low values. To better understand the parameters that affect liquid-liquid phase separation in atmospheric particles, we studied the effects of molecular weight and temperature on liquid-liquid phase separation in particles containing one organic species mixed with either ammonium sulfate or ammonium bisulfate. In the molecular-weight-dependent studies, we measured liquid-liquid phase separation relative humidity (SRH) in particles containing ammonium sulfate and organic species with large molecular weights (up to $1153 \mathrm{Da}$ ). These results were combined with recent studies of liquidliquid phase separation in the literature to assess if molecular weight is a useful parameter for predicting SRH. The combined results, which include results from 33 different particle types, illustrate that SRH does not depend strongly on molecular weight (i.e., a clear relationship between molecular weight and SRH was not observed). In the temperaturedependent studies, we measured liquid-liquid phase separation in particles containing ammonium sulfate mixed with 20 different organic species at $244 \pm 1 \mathrm{~K}, 263 \pm 1 \mathrm{~K}$, and $278 \pm 1 \mathrm{~K}$; a few particles were also studied at $290 \pm 1 \mathrm{~K}$. These new results were combined with previous measurements of the same particle types at $290 \pm 1 \mathrm{~K}$. The combined SRH data illustrate that for the organic-ammonium sulfate particles studied, the SRH does not depend strongly on temperature. At most the SRH varied by $9.7 \%$ as the temperature varied from 290 to $244 \mathrm{~K}$. The high SRH values (>65\%) in these experiments may explain the lack of temperature dependence. Since water is a plasticizer, high rela-
\end{abstract}

tive humidities can lead to high water contents, low viscosities, and high diffusion rates in the particles. For these cases, unless the temperature is very low, liquid-liquid phase separation is not expected to be kinetically inhibited. The occurrence of liquid-liquid phase separation and SRH did depend strongly on temperature over the range of $290-244 \mathrm{~K}$ for particles containing $\alpha$,4-dihydroxy-3-methoxybenzeneacetic acid mixed with ammonium bisulfate. For this particle type, a combination of low temperatures and low water content likely favored kinetic inhabitation of the liquid-liquid phase separation by slow diffusion rates in highly viscous particles. The combined results suggest that liquid-liquid phase separation is likely a common occurrence in atmospheric particles at temperatures from 244-290 K, although particles that do not undergo liquid-liquid phase separation are also likely common.

\section{Introduction}

A large fraction of particles in the atmosphere contains both organic species and inorganic salts (Murphy and Thomson, 1997; Murphy et al., 1998, 2006; Middlebrook et al., 1998; Buzorius et al., 2002; Murphy, 2005; Tolocka et al., 2005; Chen et al., 2009; Pratt and Prather, 2010). Ammonium sulfate and ammonium bisulfate are both common inorganic salts in these particles (Dibb et al., 1996, 2000; Huebert et al., 1998; Talbot et al., 1998; Lee et al., 2003). The types of organic species in these particles are numerous, with only around $10 \%$ of the mass of these organic species identified at the molecular level (Hamilton et al., 2004; Goldstein 
and Galbally, 2007; Decesari et al., 2006; Hallquist et al., 2009). Organic functional groups found in mixed organicinorganic salt particles include carboxylic acids, alcohols, oxidized aromatic compounds, ethers, and esters (FinlaysonPitts and Pitts, 2000; Seinfeld and Pandis, 2006; Decesari et al., 2006; Hallquist et al., 2009; Takahama et al., 2011; Rogge et al., 1993; Saxena and Hildemann, 1996; FinlaysonPitts and Pitts, 1997; Day et al., 2009; Gilardoni et al., 2009; Liu et al., 2009; Russell et al., 2009, 2011; Fu et al., 2011; Fuzzi et al., 2001). The molecular weight of organic molecules in these mixed particles is thought to range from less than $100 \mathrm{Da}$ to as high as $1000 \mathrm{Da}$ (Gao et al., 2004; Tolocka et al., 2004; Kalberer et al., 2004; Nguyen et al., 2010). In addition, the average oxygen-to-carbon elemental ratios $(\mathrm{O}: \mathrm{C})$ of the organic material in ambient particles generally range from 0.1 to 1.0 (Chen et al., 2009; Aiken et al., 2008; DeCarlo et al., 2008; Jimenez et al., 2009; Hawkins et al., 2010; Heald et al., 2010; Ng et al., 2010; Takahama et al., 2011), while the average organic-to-inorganic mass ratios (OIR) of atmospheric particles generally range from 0.2 to 3.5 (Chen et al., 2009; Zhang et al., 2007; Jimenez et al., 2009).

When the relative humidity varies in the atmosphere, mixed organic-inorganic salt particles can undergo different phase transitions, including efflorescence and deliquescence (Martin, 2000; Brooks et al., 2002; Choi and Chan, 2002; Brooks et al., 2003; Chan and Chan, 2003; Wise et al., 2003; Braban and Abbatt, 2004; Pant et al., 2004; Parsons et al., 2004a; Badger et al., 2006; Chang and Pankow, 2006; Erdakos et al., 2006; Parsons et al., 2006; Salcedo, 2006; Ling and Chan, 2008; Treuel et al., 2009; Bodsworth et al., 2010). More recent laboratory measurements and calculations have focused on liquid-liquid phase separation (Clegg et al., 2001; Pankow, 2003; Marcolli and Krieger, 2006; Anttila et al., 2007; Buajarern et al., 2007; Zuend et al., 2008; Ciobanu et al., 2009; Kwamena et al., 2010; Prisle et al., 2010; Zuend et al., 2010, 2011; Bertram et al., 2011; Reid et al., 2011; Smith et al., 2011; Krieger et al., 2012; Pöhlker et al., 2012; Smith et al., 2012; Song et al., 2012a, b; You et al., 2012; Zuend and Seinfeld, 2012; Drozd et al., 2013; Shiraiwa et al., 2013; Song et al., 2013; Veghte et al., 2013; You et al., 2013; Zuend and Seinfeld, 2013; Veghte et al., 2014). Liquid-liquid phase separation in the atmospheric particles can influence the partitioning of organic molecules between the gas and the particle phase (Seinfeld et al., 2001; Chang and Pankow, 2006; Zuend et al., 2010; Shiraiwa et al., 2013) and influence the reactive uptake of important gas-phase molecules, such as $\mathrm{N}_{2} \mathrm{O}_{5}$, into atmospheric particles (Anttila et al., 2006; Folkers et al., 2003; Escoreia et al., 2010; Cosman and Bertram, 2008; Park et al., 2007; Thornton and Abbatt, 2005; McNeill et al., 2006; Gaston et al., 2014). Liquid-liquid phase separation can also influence the deliquescence and efflorescence relative humidity of mixed organic-inorganic salt particles (Bertram et al., 2011; Smith et al., 2012; Song et al., 2013).
In addition, liquid-liquid phase separation can alter the ice nucleation properties of particles (Schill and Tolbert, 2013).

Recent work has investigated different parameters that influence liquid-liquid phase separation in particles containing mixtures of organic species and inorganic salts (You et al., 2014). Understanding the parameters that affect these transitions is necessary for predicting these phase transitions in atmospheric particles. Studies have shown that $\mathrm{O}: \mathrm{C}$ is an important parameter for predicting liquid-liquid phase separation in these particles, with this phase transition always observed for $\mathrm{O}: \mathrm{C}$ less than 0.5 , frequently observed for $\mathrm{O}: \mathrm{C}$ values between 0.5 and 0.8 , and never observed for $\mathrm{O}: \mathrm{C}$ values greater than 0.8 (Bertram et al., 2011; Song et al., 2012a, b; You et al., 2013). Measurements have also illustrated that the type of functional groups can also influence the relative humidity required for liquid-liquid phase separation when the $\mathrm{O}: \mathrm{C}$ of the organic material is in the range of approximately 0.5 to 0.8 (Song et al., 2012b). On the other hand, the occurrence of liquid-liquid phase separation is not a strong function of the OIR or the number of organic species (Marcolli and Krieger, 2006; Ciobanu et al., 2009; Bertram et al., 2011; Song et al., 2012a,b; Schill and Tolbert, 2013). In addition, the occurrence of liquid-liquid phase separation may not be a strong function of the type of inorganic salt for $\mathrm{O}: \mathrm{C}$ $\geq 0.8$ and $\leq 0.5$, but, in the range of 0.5 to 0.8 , the occurrence of liquid-liquid phase separation can depend on the salt type (You et al., 2013).

In the following paper, we investigate if the molecular weight of the organic material and the temperature of the particles influence liquid-liquid phase separation in particles containing organic species and inorganic salts. Molecular weight of the organic molecules is of interest because viscosity of organic-inorganic salt mixtures can depend roughly on the molecular weight of the organic species (Greener et al., 1993; Zobrist et al., 2008; Koop et al., 2011; Saukko et al., 2012), and at high molecular weights, liquid-liquid phase separation may become kinetically inhibited in highly viscous solutions. The effect of the molecular weight of the organic material on the occurrence of liquid-liquid phase separation in mixed organic-inorganic salt particles has not been explored.

Temperature is of interest since temperature ranges from approximately 220 to $300 \mathrm{~K}$ in the troposphere and can influence the thermodynamics and kinetics of liquid-liquid phase separation. As an example of the effect of temperature on the thermodynamics of liquid-liquid phase transitions, consider the binary mixture of water and butanol. At room temperature the binary mixture is partially immiscible. However, as the temperature increases, the region of immiscibility decreases until the upper critical solution temperature is reached. At higher temperatures the binary mixture is completely miscible. Certain mixtures can also have lower critical solution temperatures due to an increase in hydrogen bonding as the solution temperature decreases (Levine, 2009). Temperature may also influence the kinetics of liquid- 
liquid phase transitions. Some mixtures of organic species and inorganic salts can become highly viscous at lower temperatures and low relative humidities (Tong et al., 2011; Zobrist et al., 2008; Koop et al., 2011; Zobrist et al., 2011; Murray, 2008; Mikhailov et al., 2009; Saukko et al., 2012). At these low temperatures and relative humidities, liquid-liquid phase separation may be kinetically inhibited due to diffusion limitations. Only two studies have investigated liquid-liquid phase separation in mixed organic-inorganic salt particles at temperatures below $290 \mathrm{~K}$. Bertram et al. (2011) reported that separation relative humidity (SRH) results were similar at $273 \mathrm{~K}$ and $290 \mathrm{~K}$ for particles containing ammonium sulfate and 1,2,6-hexanetriol (Bertram et al., 2011). Schill and Tolbert, 2013 reported that SRH results were similar for temperatures from 240 to $265 \mathrm{~K}$ for particles containing ammonium sulfate mixed with 1,2,6-hexanetriol and particles containing ammonium sulfate, 1,2,6-hexanetriol, and 2,2,6,6tetrakis(hydroxymethyl)cyclohexanol (Schill and Tolbert, 2013).

Here we carried out a systematic study of the effect of molecular weight of the organic material on liquid-liquid phase separation at $290 \pm 1 \mathrm{~K}$. We first studied liquid-liquid phase separation in particles containing ammonium sulfate mixed with 1 of 10 organic species, with molecular weights up to $1153 \mathrm{Da}$. The data from these studies were then combined with recent studies of liquid-liquid phase separation in particles reported in the literature (You et al., 2013) to assess if molecular weight is a useful parameter to predict the occurrence of liquid-liquid phase separation and the liquid-liquid phase separation relative humidity.

To gain a better understanding of the effect of temperature on liquid-liquid phase separation in mixed organicinorganic salt particles, we investigated liquid-liquid phase separation in particles containing ammonium sulfate mixed with 1 of 20 organic species at $244 \pm 1 \mathrm{~K}, 263 \pm 1 \mathrm{~K}$, and $278 \pm 1 \mathrm{~K}$, respectively. Some of these particle types were also studied at $290 \pm 1 \mathrm{~K}$. These new data were combined with previous measurements of liquid-liquid phase separation at $290 \pm 1 \mathrm{~K}$ by You et al. (2013) to assess the effect of temperature on liquid-liquid phase separation in mixed organic-ammonium sulfate particles.

We also investigated liquid-liquid phase separation in particles containing ammonium bisulfate mixed with $\alpha, 4$ dihydroxy-3-methoxybenzeneacetic acid at temperatures of $244 \pm 1 \mathrm{~K}, 263 \pm 1 \mathrm{~K}$, and $278 \pm 1 \mathrm{~K}$. This system was studied since it has a relatively low SRH value $(38 \%)$ at $290 \pm 1 \mathrm{~K}$ and, hence, has relatively low water content at the onset of liquid-liquid phase separation. In addition to temperature and molecular weight, water content is likely important for the kinetics of liquid-liquid phase separations as the viscosity and diffusion rates within the particles are expected to be sensitive to water content (Koop et al., 2011; Renbaum-Wolff et al., 2013; Power et al., 2013; Kidd et al., 2014).

\section{Experimental}

\subsection{Sample preparation and apparatus}

Solutions of ammonium sulfate or ammonium bisulfate and one organic species were prepared in high-purity water (Millipore, $18.2 \mathrm{M} \Omega \mathrm{cm}$ ) with an OIR of $2.0 \pm 0.1$. The solutions were then nebulized to produce submicron particles, which impacted onto a hydrophobic glass slide (Hampton Research) and coagulated into supermicron droplets. Water was then evaporated to generate mixed organic-inorganic salt particles with lateral dimensions ranging from 10 to $35 \mu \mathrm{m}$.

The glass slide supporting the mixed organic-inorganic salt particles was mounted to a temperature- and relativehumidity-controlled flow cell, which was coupled to an optical reflectance microscope (Zeiss Axiotech; $500 \times$ objective) (Koop et al., 2000; Parsons et al., 2004b; Pant et al., 2006; Bodsworth et al., 2010). To control the relative humidity in the flow cell, dry and humidified nitrogen gas flows were combined and continuously passed through the cell. The total flow rate was approximately $1.5 \mathrm{~L} \mathrm{~min}^{-1}$. While the RH was decreased, liquid-liquid phase separation was identified by monitoring the change in morphology of the particles. The relative humidity of the gas was determined with a chilled mirror hygrometer (General Eastern, Model 1311DR). The hygrometer was calibrated prior to experiments at each temperature $(244 \pm 1 \mathrm{~K}, 263 \pm 1 \mathrm{~K}, 278 \pm 1 \mathrm{~K}$, and $290 \pm 1 \mathrm{~K}$ ) by measuring the deliquescence relative humidity (DRH) of ammonium sulfate particles and comparing the measured DRH value to the DRH value predicted with the Extended Aerosol Inorganics Model (E-AIM model) (Clegg et al., 1998). The uncertainty $(2 \sigma)$ of the hygrometer was $\pm 2.5 \% \mathrm{RH}$ after calibration based on reproducibility of the DRH measurements.

\subsection{Molecular-weight-dependent studies}

Particles containing ammonium sulfate mixed with 1 of 10 organic species were studied at $290 \pm 1 \mathrm{~K}$ (see Table 1). Most of the previous laboratory studies of liquid-liquid phase separation in particles containing organic species mixed with ammonium sulfate used organic species with molecular weight less than $200 \mathrm{Da}$ (Bertram et al., 2011; Song et al., 2012a, b; You et al., 2013). To complement these previous studies, in the current study we investigated particles containing ammonium sulfate and organic species with molecular weight ranging from 180 to $1153 \mathrm{Da}$ (see Table 1). The specific organic species selected for these studies (Table 1) also had a relatively wide range of $\mathrm{O}: \mathrm{C}$ values. The glass transition temperatures of the organics studied covered at least the range of $223 \mathrm{~K}$ to $412 \mathrm{~K}$ (see Table 1). In all the studies, the organic-to-inorganic mass ratio was $2.0 \pm 0.1$. This value was chosen so that the current studies could be compared with the previous studies by You et al. (2013), who 
Table 1. List of the 10 organic species used in molecular-weight-dependent measurements. Each organic species was separately mixed with ammonium sulfate to make particles, and liquid-liquid phase separation was studied in these particles at $290 \pm 1 \mathrm{~K}$.

\begin{tabular}{|c|c|c|c|c|c|c|}
\hline Compounds & Formula & $\begin{array}{l}\text { Molecular } \\
\text { weight (Da) }\end{array}$ & $\mathrm{O}: \mathrm{C}$ & $\begin{array}{l}\text { Functional } \\
\text { group }(s)\end{array}$ & $\begin{array}{l}\text { Glass transition } \\
\text { temperature, } T_{\mathrm{g}}(\mathrm{K})\end{array}$ & $\begin{array}{l}\text { References } \\
\text { for } T_{\mathrm{g}}\end{array}$ \\
\hline Glucose & $\mathrm{C}_{6} \mathrm{H}_{12} \mathrm{O}_{6}$ & 180.2 & 1 & alcohol, ether & $296.1 \pm 3.1$ & Zobrist et al., 2008 \\
\hline $\begin{array}{l}\text { Poly(ethylene } \\
\text { glycol) } \\
\text { bis(carboxymethyl) } \\
\text { ether }\end{array}$ & $\mathrm{C}_{2 n+4} \mathrm{H}_{4 n+6} \mathrm{O}_{n+5}$ & 250 & 0.83 & alcohol, ether & - & - \\
\hline Sucrose & $\mathrm{C}_{12} \mathrm{H}_{22} \mathrm{O}_{11}$ & 342.3 & 0.92 & alcohol, ether & $335.7 \pm 3.6$ & Zobrist et al., 2008 \\
\hline $\begin{array}{l}\text { Poly(ethylene } \\
\text { glycol) }\end{array}$ & $\mathrm{C}_{2 n} \mathrm{H}_{4 n+2} \mathrm{O}_{n+1}$ & 400 & 0.56 & alcohol, ether & 223 & Faucher et al., 1966 \\
\hline Ouabain & $\mathrm{C}_{29} \mathrm{H}_{44} \mathrm{O}_{12}$ & 584 & 0.41 & $\begin{array}{l}\text { alcohol, ether, } \\
\text { ester, C-C } \\
\text { double bonds }\end{array}$ & $373^{\mathrm{a}}$ & Koop et al., 2011 \\
\hline Raffinose & $\mathrm{C}_{18} \mathrm{H}_{32} \mathrm{O}_{16}$ & 594.5 & 0.89 & alcohol, ether & $395.7 \pm 21.6$ & Zobrist et al., 2008 \\
\hline $\begin{array}{l}\text { Poly(ethylene } \\
\text { glycol) }\end{array}$ & $\mathrm{C}_{2 n} \mathrm{H}_{4 n+2} \mathrm{O}_{n+1}$ & 600 & 0.54 & alcohol, ether & 231 & Faucher et al., 1966 \\
\hline Maltopentaose & $\mathrm{C}_{30} \mathrm{H}_{52} \mathrm{O}_{26}$ & 829 & 0.87 & alcohol, ether & 398 & Slade and Levine, 1994 \\
\hline $\begin{array}{l}\text { Poly(ethylene } \\
\text { glycol) }\end{array}$ & $\mathrm{C}_{2 n} \mathrm{H}_{4 n+2} \mathrm{O}_{n+1}$ & 900 & 0.53 & alcohol, ether & $231-245$ & Faucher et al., 1966 \\
\hline Maltoheptaose & $\mathrm{C}_{42} \mathrm{H}_{72} \mathrm{O}_{36}$ & 1153 & 0.86 & alcohol, ether & 412 & Slade and Levine, 1994 \\
\hline
\end{tabular}

${ }^{\text {a }} T_{\mathrm{g}}$ values are estimates based on the melting points of those organic compounds using the results from Koop et al., 2011.

- Literature data not available.

also used an OIR of $2.0 \pm 0.1$. In addition, this OIR value is in the range of OIR values observed in many field studies (Zhang et al., 2007; Jimenez et al., 2009).

In a typical experiment, the RH in the cell was ramped down at a rate of $0.4-0.6 \% \mathrm{RH} \mathrm{min}-1$ while the temperature of the cell was held at $290 \pm 1 \mathrm{~K}$. At the same time, images of the particles were captured continuously until one of the following conditions occurred: liquid-liquid phase separation was observed, the particles effloresced, or the RH reached $\leq 0.5 \%$. For each type of particle, experiments were repeated at least three times. All of the organic species were purchased from Sigma-Aldrich and had purities $\geq 95 \%$, except for maltoheptaose, which had a purity $\geq 90 \%$.

\subsection{Temperature-dependent studies}

Particles consisting of ammonium sulfate mixed with 1 of 20 organic species were studied (see Table 2) at $244 \pm 1 \mathrm{~K}$, $263 \pm 1 \mathrm{~K}$, and $278 \pm 1 \mathrm{~K}$, as well as $290 \pm 1 \mathrm{~K}$ for a few of these particle types. For these studies, we chose the same particle types previously studied by You et al. (2013) at $290 \pm 1 \mathrm{~K}$. These particle types cover a wide range of $\mathrm{O}: \mathrm{C}$ values and included functional groups found in atmospheric particles. Also, ammonium sulfate is one of the most common inorganic salts found in the atmosphere. In addition to picking the particles types previously studied by You et al. (2013), we also studied two additional organic species mixed with ammonium sulfate. These two organic species were raffinose and poly(ethylene glycol) diacrylate. These two species were chosen since they had relatively high molecular weights. An OIR value of $2.0 \pm 0.1$ was used in all the studies, consistent with You et al. (2013). The glass transition temperatures of the organic species studied cover the range of at least $192 \mathrm{~K}$ to $396 \mathrm{~K}$.

In addition to studying particles consisting of ammonium sulfate mixed with 1 of 20 organic species, we also studied particles containing ammonium bisulfate mixed with $\alpha, 4-$ dihydroxy-3-methoxybenzeneacetic acid at temperatures of $244 \pm 1 \mathrm{~K}, 263 \pm 1 \mathrm{~K}$, and $278 \pm 1 \mathrm{~K}$. As mentioned in the Introduction, this system was studied since it has a low SRH value $(38 \%)$ at $290 \pm 1 \mathrm{~K}$ and hence has relatively low water content at the onset of liquid-liquid phase separation.

The organic species studied were purchased from SigmaAldrich with purities $\geq 98 \%$. All these organic species were used without further purification. In a typical temperaturedependent experiment, the $\mathrm{RH}$ was ramped down at a rate of around $0.1-0.5 \% \mathrm{RH} \mathrm{min}{ }^{-1}$. Images were recorded in the same way as the molecular-weight-dependent studies. 
Table 2. Summary of the 20 organic species used in temperature-dependent experiments. Each organic species was separately mixed with ammonium sulfate to make particles, and liquid-liquid phase separation was studied in these particles at $244 \pm 1 \mathrm{~K}, 263 \pm 1 \mathrm{~K}$, and $278 \pm 1 \mathrm{~K}$. Two of the organic species (poly(ethylene glycol) diacrylate and raffinose) mixed with ammonium sulfate were also studied at $290 \pm 1 \mathrm{~K}$.

\begin{tabular}{|c|c|c|c|c|c|c|}
\hline Compounds & Formula & $\mathrm{O}: \mathrm{C}$ & $\begin{array}{l}\text { Molecular } \\
\text { weight }(\mathrm{Da})\end{array}$ & $\begin{array}{l}\text { Functional } \\
\text { group(s) }\end{array}$ & $\begin{array}{l}\text { Glass transition } \\
\text { temperature, } T_{\mathrm{g}}(\mathrm{K})\end{array}$ & $\begin{array}{l}\text { References } \\
\text { for } T_{\mathrm{g}}\end{array}$ \\
\hline 2,5-hexanediol & $\mathrm{C}_{6} \mathrm{H}_{14} \mathrm{O}_{2}$ & 0.33 & 118.2 & alcohol & $192.4 \pm 1.3$ & Zobrist et al., 2008 \\
\hline $\begin{array}{l}\text { Poly(propylene } \\
\text { glycol) }\end{array}$ & $\mathrm{C}_{3 n} \mathrm{H}_{6 n+2} \mathrm{O}_{n+1}$ & 0.38 & 425 & alcohol, ether & - & - \\
\hline $\begin{array}{l}\text { Poly(ethylene } \\
\text { glycol) } \\
\text { diacrylate }\end{array}$ & $\mathrm{C}_{2 n+6} \mathrm{H}_{4 n+6} \mathrm{O}_{n+3}$ & 0.5 & 575 & $\begin{array}{l}\text { ester, ether, } \mathrm{C}-\mathrm{C} \\
\text { double bonds }\end{array}$ & - & - \\
\hline $\begin{array}{l}\text { Poly(ethylene } \\
\text { glycol) } 900\end{array}$ & $\mathrm{C}_{2 n} \mathrm{H}_{4 n+2} \mathrm{O}_{n+1}$ & 0.53 & 900 & alcohol, ether & $231-245^{\mathrm{a}}$ & Faucher et al., 1966 \\
\hline $\begin{array}{l}\alpha, 4 \text {-dihydroxy-3- } \\
\text { methoxybenzeneacet } \\
\text { acid }\end{array}$ & $\mathrm{C}_{9} \mathrm{H}_{10} \mathrm{O}_{5}$ & 0.56 & 198.2 & $\begin{array}{l}\text { alcohol, aromatic, } \\
\text { carboxylic acid, } \\
\text { ether }\end{array}$ & $293.6 \pm 6.6$ & Zobrist et al., 2008 \\
\hline $\begin{array}{l}\text { Diethylmalonic } \\
\text { acid }\end{array}$ & $\mathrm{C}_{7} \mathrm{H}_{12} \mathrm{O}_{4}$ & 0.57 & 160.2 & carboxylic acid & $282^{\mathrm{b}}$ & Koop et al., 2011 \\
\hline $\begin{array}{l}3,3- \\
\text { dimethylglutaric } \\
\text { acid }\end{array}$ & $\mathrm{C}_{7} \mathrm{H}_{12} \mathrm{O}_{4}$ & 0.57 & 160.2 & carboxylic acid & $261^{b}$ & Koop et al., 2011 \\
\hline $\begin{array}{l}2,5- \\
\text { hydroxybenzoic } \\
\text { acid }\end{array}$ & $\mathrm{C}_{7} \mathrm{H}_{6} \mathrm{O}_{4}$ & 0.57 & 154.2 & $\begin{array}{l}\text { carboxylic } \\
\text { acid, aromatic }\end{array}$ & $225^{\mathrm{b}}$ & Koop et al., 2011 \\
\hline $\begin{array}{l}\text { Poly(ethylene } \\
\text { glycol) } \\
300\end{array}$ & $\mathrm{C}_{2 n} \mathrm{H}_{4 n+2} \mathrm{O}_{n+1}$ & 0.58 & 300 & alcohol, ether & $203-223$ & Faucher et al., 1966 \\
\hline $\begin{array}{l}\text { Poly(ethylene } \\
\text { glycol) } \\
200\end{array}$ & $\mathrm{C}_{2 n} \mathrm{H}_{4 n+2} \mathrm{O}_{n+1}$ & 0.63 & 200 & alcohol, ether & 203 & Faucher et al., 1966 \\
\hline $\begin{array}{l}\text { Poly(ethylene } \\
\text { glycol) } \\
\text { bis(carboxymethyl) } \\
\text { ether }\end{array}$ & $\mathrm{C}_{2 n+4} \mathrm{H}_{4 n+6} \mathrm{O}_{n+5}$ & 0.63 & 600 & alcohol, ether & - & - \\
\hline $\begin{array}{l}\text { 2-methylglutaric } \\
\text { acid }\end{array}$ & $\mathrm{C}_{6} \mathrm{H}_{10} \mathrm{O}_{4}$ & 0.67 & 146.1 & carboxylic acid & $247^{b}$ & Koop et al., 2011 \\
\hline $\begin{array}{l}2,2- \\
\text { dimethylsuccinic } \\
\text { acid }\end{array}$ & $\mathrm{C}_{6} \mathrm{H}_{10} \mathrm{O}_{4}$ & 0.67 & 146.2 & carboxylic acid & $289^{\mathrm{b}}$ & Koop et al., 2011 \\
\hline Diethyl L-tartrate & $\mathrm{C}_{8} \mathrm{H}_{14} \mathrm{O}_{6}$ & 0.75 & 206.2 & alcohol, ether & - & - \\
\hline Glycerol & $\mathrm{C}_{3} \mathrm{H}_{8} \mathrm{O}_{3}$ & 1.00 & 92.1 & alcohol & $193.3 \pm 1.1$ & Zobrist et al., 2008 \\
\hline Glutaric acid & $\mathrm{C}_{5} \mathrm{H}_{8} \mathrm{O}_{4}$ & 0.8 & 132.1 & carboxylic acid & $258^{\mathrm{b}}$ & Koop et al., 2011 \\
\hline Levoglucosan & $\mathrm{C}_{6} \mathrm{H}_{10} \mathrm{O}_{5}$ & 0.83 & 162.1 & alcohol, ester & $319^{\mathrm{b}}$ & Koop et al., 2011 \\
\hline Raffinose & $\mathrm{C}_{18} \mathrm{H}_{32} \mathrm{O}_{16}$ & 0.89 & 594.5 & alcohol, ester & $395.7 \pm 21.6$ & Zobrist et al., 2008 \\
\hline Citric acid & $\mathrm{C}_{6} \mathrm{H}_{8} \mathrm{O}_{7}$ & 1.17 & 192.1 & $\begin{array}{l}\text { alcohol, } \\
\text { carboxylic acid }\end{array}$ & 280.1 & Bodsworth et al., 2010 \\
\hline Malonic acid & $\mathrm{C}_{3} \mathrm{H}_{4} \mathrm{O}_{4}$ & 1.33 & 104.1 & carboxylic acid & $286^{\mathrm{b}}$ & Koop et al., 2011 \\
\hline
\end{tabular}

\footnotetext{
${ }^{a} T_{\mathrm{g}}$ value is an estimate based on the molecular weight of the ploy (ethylene glycol 900) from Faucher et al., 1966.

${ }^{\mathrm{b}} T_{\mathrm{g}}$ values are estimates based on the melting points of those organic compounds using the results from Koop et al., 2011.

- Literature data not available.
} 
Table 3. Combined data set used to assess the effect of molecular weight on SRH in mixed organic-ammonium sulfate particles. This data set includes the 10 types of particles studied here (see Table 1) and the SRH results of 23 types of particles containing single organic species and ammonium sulfate studied by You et al. (2013). OIR $=2.0 \pm 0.1$ in all the experiments. Uncertainties are $95 \%$ confidence intervals considering $\sigma$ of multiple SRH measurements and the uncertainty from the calibration.

\begin{tabular}{|c|c|c|c|c|c|}
\hline Compounds & Formula & $\begin{array}{l}\text { Molecular } \\
\text { weight }(\mathrm{Da})\end{array}$ & $\mathrm{O}: \mathrm{C}$ & SRH $(\%)$ & Reference \\
\hline Glycerol & $\mathrm{C}_{3} \mathrm{H}_{8} \mathrm{O}_{3}$ & 92.1 & 1 & not observed & You et al., 2013 \\
\hline Malonic acid & $\mathrm{C}_{3} \mathrm{H}_{4} \mathrm{O}_{4}$ & 104.1 & 1.33 & not observed & You et al., 2013 \\
\hline Maleic acid & $\mathrm{C}_{4} \mathrm{H}_{4} \mathrm{O}_{4}$ & 116.1 & 1 & not observed & You et al., 2013 \\
\hline 2,5-hexanediol & $\mathrm{C}_{6} \mathrm{H}_{14} \mathrm{O}_{2}$ & 118.2 & 0.33 & $88.8 \pm 7.1$ & You et al., 2013 \\
\hline Glutaric acid & $\mathrm{C}_{5} \mathrm{H}_{8} \mathrm{O}_{4}$ & 132.1 & 0.8 & not observed & You et al., 2013 \\
\hline Malic acid & $\mathrm{C}_{4} \mathrm{H}_{6} \mathrm{O}_{5}$ & 134.1 & 1.25 & not observed & You et al., 2013 \\
\hline 1,2,6-hexanetriol & $\mathrm{C}_{6} \mathrm{H}_{14} \mathrm{O}_{3}$ & 134.2 & 0.5 & $76.7 \pm 6.2$ & You et al., 2013 \\
\hline 2-methylglutaric acid & $\mathrm{C}_{6} \mathrm{H}_{10} \mathrm{O}_{4}$ & 146.1 & 0.67 & $75.3 \pm 6.4$ & You et al., 2013 \\
\hline 2,2-dimethylsuccinic acid & $\mathrm{C}_{6} \mathrm{H}_{10} \mathrm{O}_{4}$ & 146.2 & 0.67 & not observed & You et al., 2013 \\
\hline 2,5-hydroxybenzoic acid & $\mathrm{C}_{7} \mathrm{H}_{6} \mathrm{O}_{4}$ & 154.2 & 0.57 & not observed & You et al., 2013 \\
\hline Diethylmalonic acid & $\mathrm{C}_{7} \mathrm{H}_{12} \mathrm{O}_{4}$ & 160.2 & 0.57 & $89.2 \pm 4.2$ & You et al., 2013 \\
\hline 3,3-dimethylglutaric acid & $\mathrm{C}_{7} \mathrm{H}_{12} \mathrm{O}_{4}$ & 160.2 & 0.57 & $89.1 \pm 6.9$ & You et al., 2013 \\
\hline Levoglucosan & $\mathrm{C}_{6} \mathrm{H}_{10} \mathrm{O}_{5}$ & 162.1 & 0.83 & not observed & You et al., 2013 \\
\hline Glucose & $\mathrm{C}_{6} \mathrm{H}_{12} \mathrm{O}_{6}$ & 180.2 & 1 & not observed & Current study \\
\hline Suberic acid monomethyl ester & $\mathrm{C}_{9} \mathrm{H}_{16} \mathrm{O}_{4}$ & 188.2 & 0.44 & $100 \pm 6.2$ & You et al., 2013 \\
\hline Citric acid & $\mathrm{C}_{6} \mathrm{H}_{8} \mathrm{O}_{7}$ & 192.1 & 1.17 & not observed & You et al., 2013 \\
\hline$\alpha, 4$-dihydroxy-3-methoxybenzeneacetic acid & $\mathrm{C}_{9} \mathrm{H}_{10} \mathrm{O}_{5}$ & 198.2 & 0.56 & $72.6 \pm 6.3$ & You et al., 2013 \\
\hline Poly(ethylene glycol) & $\mathrm{C}_{2 n} \mathrm{H}_{4 n+2} \mathrm{O}_{n+1}$ & 200 & 0.63 & $79.8 \pm 7.4$ & You et al., 2013 \\
\hline Diethyl L-tartrate & $\mathrm{C}_{8} \mathrm{H}_{14} \mathrm{O}_{6}$ & 206.2 & 0.75 & $90.2 \pm 6.6$ & You et al., 2013 \\
\hline Poly(ethylene glycol) bis(carboxymethyl) ether & $\mathrm{C}_{2 n+4} \mathrm{H}_{4 n+6} \mathrm{O}_{n+5}$ & 250 & 0.83 & $67.6 \pm 6.2$ & Current study \\
\hline Diethyl sebacate & $\mathrm{C}_{14} \mathrm{H}_{26} \mathrm{O}_{4}$ & 258.4 & 0.29 & $100 \pm 6.2$ & You et al., 2013 \\
\hline Poly(ethylene glycol) & $\mathrm{C}_{2 n} \mathrm{H}_{4 n+2} \mathrm{O}_{n+1}$ & 300 & 0.58 & $86.7 \pm 6.4$ & You et al., 2013 \\
\hline Sucrose & $\mathrm{C}_{12} \mathrm{H}_{22} \mathrm{O}_{11}$ & 342.3 & 0.92 & not observed & Current study \\
\hline Poly(ethylene glycol) & $\mathrm{C}_{2 n} \mathrm{H}_{4 n+2} \mathrm{O}_{n+1}$ & 400 & 0.56 & $88.3 \pm 6.6$ & Current study \\
\hline Poly(propylene glycol) & $\mathrm{C}_{3 n} \mathrm{H}_{6 n+2} \mathrm{O}_{n+1}$ & 425 & 0.38 & $94.1 \pm 6.7$ & You et al., 2013 \\
\hline Poly(ethylene glycol) diacrylate & $\mathrm{C}_{2 n+6} \mathrm{H}_{4 n+6} \mathrm{O}_{n+3}$ & 575 & 0.5 & $94.7 \pm 6.2$ & You et al., 2013 \\
\hline Ouabain & $\mathrm{C}_{29} \mathrm{H}_{44} \mathrm{O}_{12}$ & 584 & 0.41 & $90.1 \pm 6.8$ & Current study \\
\hline Raffinose & $\mathrm{C}_{18} \mathrm{H}_{32} \mathrm{O}_{16}$ & 594.5 & 0.89 & not observed & Current study \\
\hline Poly(ethylene glycol) & $\mathrm{C}_{2 n} \mathrm{H}_{4 n+2} \mathrm{O}_{n+1}$ & 600 & 0.54 & $89.5 \pm 6.3$ & Current study \\
\hline Poly(ethylene glycol) bis(carboxymethyl) ether & $\mathrm{C}_{2 n+4} \mathrm{H}_{4 n+6} \mathrm{O}_{n+5}$ & 600 & 0.63 & $92.0 \pm 6.3$ & You et al., 2013 \\
\hline Maltopentaose & $\mathrm{C}_{30} \mathrm{H}_{52} \mathrm{O}_{26}$ & 829 & 0.87 & not observed & Current study \\
\hline Poly(ethylene glycol) & $\mathrm{C}_{2 n} \mathrm{H}_{4 n+2} \mathrm{O}_{n+1}$ & 900 & 0.53 & $92.9 \pm 6.4$ & Current study \\
\hline Maltoheptaose & $\mathrm{C}_{42} \mathrm{H}_{72} \mathrm{O}_{36}$ & 1153 & 0.86 & not observed & Current study \\
\hline
\end{tabular}

\section{Results and Discussion}

\subsection{Effect of molecular weight on liquid-liquid phase separation}

Particles containing ammonium sulfate mixed with 1 of 10 organic species were studied at $290 \pm 1 \mathrm{~K}$. In these studies, organic species with large molecular weights (180 to $1153 \mathrm{Da}$ ) were used. The organic-to-inorganic mass ratio was $2.0 \pm 0.1$ in all studies. The results from these studies are listed in Table 3 as well as the data from You et al., who also studied particles with an OIR of $2.0 \pm 0.1$ at $290 \pm 1 \mathrm{~K}$ (You et al., 2013). The combined data set in Table 3, which includes results of liquid-liquid phase separation for 33 different particle types, was used to determine the importance of molecular weight of the organic species on liquid-liquid phase separation.
In Fig. 1, the data from Table 3 were plotted as a function of $\mathrm{O}: \mathrm{C}$ and molecular weight. Open circles indicate that liquid-liquid phase separation was observed and stars indicate that liquid-liquid phase separation was not observed. No clear relationship between molecular weight and the occurrence of liquid-liquid phase separation was observed; however, a relationship between occurrence of liquid-liquid phase separation and $\mathrm{O}: \mathrm{C}$ was clear: liquid-liquid phase separation was always observed when $\mathrm{O}: \mathrm{C}<0.57$ (orangehatched region), was never observed when $\mathrm{O}: \mathrm{C}>0.83$ (green-hatched region), and was frequently observed when $\mathrm{O}: \mathrm{C}$ ranged from 0.57 to 0.83 . This range is slightly different than the range previously measured (0.5 to 0.8 ) (Bertram et al., 2011; Song et al., 2012a, b; You et al., 2013), which is not surprising since this range is expected to change slightly with the type of organic molecules studied. As such, there is a small uncertainty in this range. In Fig. 2, the SRH data from 


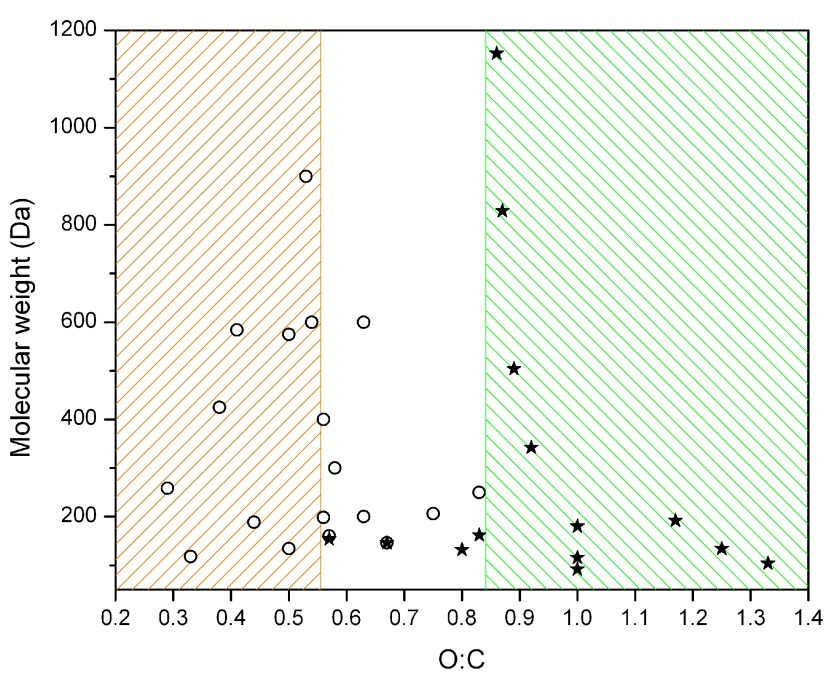

Figure 1. The effect of molecular weight and $\mathrm{O}: \mathrm{C}$ of the organic species on the occurrence of liquid-liquid phase separation in mixed organic-ammonium sulfate particles (OIR $=2.0 \pm 0.1)$. Data plotted are from the current study and You et al. (2013) and are summarized in Table 3. Open circles indicate liquid-liquid phase separation was observed, while stars indicate liquid-liquid phase separation was not observed. The orange-hatched region corresponds to the molecular weight and $\mathrm{O}: \mathrm{C}$ of the organic species when liquidliquid phase separation was always observed, and the green-hatched region corresponds to the molecular weight and $\mathrm{O}: \mathrm{C}$ of the organic species when liquid-liquid phase separation was never observed.

Table 3 were plotted as a function of molecular weight of the organic species. The colors of the symbols indicate the $\mathrm{O}: \mathrm{C}$ of organic species in the mixed particles. Data at $\mathrm{SRH}=0 \%$ indicate liquid-liquid phase separation was not observed even at the lowest relative humidity studied. Similar to Fig. 1, no correlation with molecular weight was apparent. For contrast, in Fig. 3 we show the same SRH data plotted as a function of $\mathrm{O}: \mathrm{C}$ of organic species with the color of the symbols representing the molecular weight of organic species. Consistent with previous results (Bertram et al., 2011; Song et al., 2012b), a correlation between SRH and O : C is apparent. These results suggest that $\mathrm{O}: \mathrm{C}$ is more important for predicting the occurrence of liquid-liquid phase separation in atmospherically relevant mixed organic-ammonium sulfate particles compared with molecular weight.

\subsection{Effect of temperature on liquid-liquid phase separation}

In the temperature-dependent experiments, particles containing ammonium sulfate mixed with 1 of 20 organic species were studied at $244 \pm 1 \mathrm{~K}, 263 \pm 1 \mathrm{~K}$, and $278 \pm 1 \mathrm{~K}$. Some of the particle types were also studied at $290 \pm 1 \mathrm{~K}$. The temperature-dependent results are included in Table 4 along with results from You et al., who studied most of the same types of particles but only at $290 \pm 1 \mathrm{~K}$ (You et al., 2013).

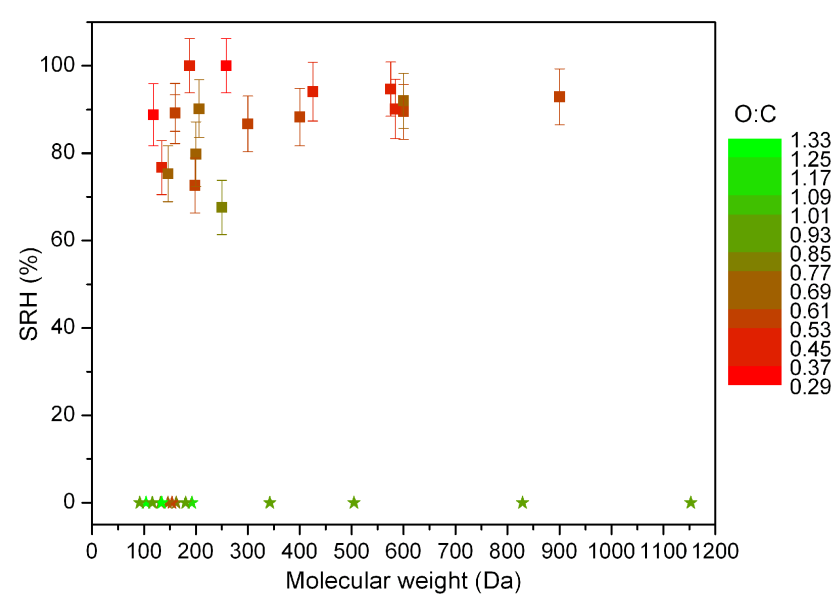

Figure 2. SRH as a function of molecular weight of organic species in the particles at $290 \pm 1 \mathrm{~K}$. The SRH results are from the current study and You et al. (2013) (see Table 3). The colors represent the $\mathrm{O}: \mathrm{C}$ of different organic species. Squares represent SRH of particles in which liquid-liquid phase separation was observed. Bars for the squares are $95 \%$ confidence intervals considering $\sigma$ of multiple SRH measurements and the uncertainty from the calibration. Stars indicate that liquid-liquid phase separation was not observed. $\mathrm{OIR}=2.0 \pm 0.1 \mathrm{in}$ all the experiments.

The combined SRH data from Table 4, which cover the temperature range of $290-244 \mathrm{~K}$, were plotted in Fig. 4a as a function of $\mathrm{O}: \mathrm{C}$ of the organic species. The temperaturedependent results show that for all the particle types and temperatures studied, liquid-liquid phase separation was always observed when $\mathrm{O}: \mathrm{C}<0.57$, frequently observed when $0.57 \leq \mathrm{O}: \mathrm{C}<0.8$, and never observed when $\mathrm{O}: \mathrm{C} \geq 0.8$. We conclude that the $\mathrm{O}: \mathrm{C}$ range at which liquid-liquid phase separation was observed at $290-293 \mathrm{~K}$ in previous studies (Ciobanu et al., 2009; Bertram et al., 2011; Song et al., 2012b; You et al., 2013) is reasonably consistent with the range observed at temperatures down to $244 \pm 1 \mathrm{~K}$.

Figure 5 shows the same data as in Fig. 4a but displayed in a slightly different way. The SRH results for the 12 types of mixed organic-ammonium sulfate particles that underwent liquid-liquid phase separation in Fig. 4a are shown as a function of temperature, with the colors of the symbols representing the $\mathrm{O}: \mathrm{C}$ values of the organic species in the particles. For all the particle types included in Fig. 5, the SRH varied by less than $9.7 \% \mathrm{RH}$ as the temperature varied from 244 to $290 \mathrm{~K}$. Figures $4 \mathrm{a}$ and 5 illustrate that SRH is not a strong function of temperature for the particle types investigated. These results are consistent with earlier studies by Bertram et al. (2011) and Schill and Tolbert (2013), as discussed in the Introduction. In the Supplementary Material, we carried out a linear regression analysis to determine the level of significance of the temperature-dependent trends observed in Fig. 5. In short, 5 out of the 12 systems studied had a high correlation coefficient $(r \geq 0.94)$ between temperature 
Table 4. Combined data set used to determine the effect of temperature on SRH. This includes the measurements at $244 \pm 1 \mathrm{~K}, 263 \pm 1 \mathrm{~K}$, and $278 \pm 1 \mathrm{~K}$ in the current studies (Table 2) and results from You et al. (2013) at $290 \pm 1 \mathrm{~K}$. OIR $=2.0 \pm 0.1$ in all the experiments. Uncertainties are $95 \%$ confidence intervals considering $\sigma$ of multiple SRH measurements and the uncertainty from the calibration.

\begin{tabular}{|c|c|c|c|c|c|}
\hline \multirow[t]{2}{*}{ Compound } & \multirow[t]{2}{*}{$\mathrm{O}: \mathrm{C}$} & \multicolumn{4}{|c|}{$\mathrm{SRH}(\%)$ at different temperatures } \\
\hline & & $244 \pm 1 \mathrm{~K}$ & $263 \pm 1 \mathrm{~K}$ & $278 \pm 1 \mathrm{~K}$ & $290 \pm 1 \mathrm{~K}$ \\
\hline 2,5-hexanediol & 0.33 & $84.0 \pm 8.3$ & $84.6 \pm 6.5$ & $88.0 \pm 6.2$ & $88.8 \pm 7.1^{\mathrm{a}}$ \\
\hline Poly(propylene glycol) & 0.38 & $87.7 \pm 6.5$ & $89.4 \pm 6.7$ & $92.5 \pm 6.2$ & $94.1 \pm 6.7^{\mathrm{a}}$ \\
\hline Poly(ethylene glycol) diacrylate & 0.5 & $88.5 \pm 7.0$ & $90.4 \pm 7.2$ & $95.0 \pm 6.2$ & $94.7 \pm 6.2$ \\
\hline Poly(ethylene glycol) 900 & 0.53 & $89.2 \pm 9.2$ & $88.7 \pm 6.2$ & $91.8 \pm 6.3$ & $92.9 \pm 6.4^{\mathrm{a}}$ \\
\hline$\alpha, 4$-dihydroxy-3-methoxybenzeneacetic acid & 0.56 & $76.0 \pm 6.3$ & $67.3 \pm 8.7$ & $72.3 \pm 6.4$ & $72.6 \pm 6.3^{\mathrm{a}}$ \\
\hline Diethylmalonic acid & 0.57 & $89.8 \pm 5.6$ & $87.0 \pm 6.7$ & $88.6 \pm 6.3$ & $89.2 \pm 4.2^{\mathrm{a}}$ \\
\hline 3,3-dimethylglutaric acid & 0.57 & $98.2 \pm 4.3$ & $88.5 \pm 6.3$ & $88.5 \pm 6.3$ & $89.1 \pm 6.9^{\mathrm{a}}$ \\
\hline 2,5-hydroxybenzoic acid & 0.57 & not observed & not observed & not observed & not observed ${ }^{\mathrm{a}}$ \\
\hline Poly(ethylene glycol) 300 & 0.58 & $85.6 \pm 9.7$ & $83.6 \pm 6.5$ & $85.6 \pm 6.4$ & $87.6 \pm 6.4^{\mathrm{a}}$ \\
\hline Poly(ethylene glycol) 200 & 0.63 & $71.3 \pm 6.2$ & $77.2 \pm 6.3$ & $79.7 \pm 6.2$ & $79.8 \pm 7.4^{\mathrm{a}}$ \\
\hline Poly(ethylene glycol) bis(carboxymethyl) ether 600 & 0.63 & $87.8 \pm 7.1$ & $90.4 \pm 6.2$ & $90.4 \pm 6.6$ & $92.0 \pm 6.3^{\mathrm{a}}$ \\
\hline 2-methylglutaric acid & 0.67 & $76.7 \pm 6.6$ & $76.2 \pm 6.3$ & $76.6 \pm 6.2$ & $75.3 \pm 6.4^{\mathrm{a}}$ \\
\hline 2,2-dimethylsuccinic acid & 0.67 & not observed & not observed & not observed & not observed ${ }^{\mathrm{a}}$ \\
\hline Diethyl L-tartrate & 0.75 & $86.9 \pm 7.3$ & $85.0 \pm 6.5$ & $87.4 \pm 4.1$ & $90.2 \pm 6.6^{\mathrm{a}}$ \\
\hline Glutaric acid & 0.8 & not observed & not observed & not observed & not observed ${ }^{\mathrm{a}}$ \\
\hline Levoglucosan & 0.83 & not observed & not observed & not observed & not observed ${ }^{\mathrm{a}}$ \\
\hline Raffinose & 0.89 & not observed & not observed & not observed & not observed \\
\hline Glycerol & 1 & not observed & not observed & not observed & not observed ${ }^{\mathrm{a}}$ \\
\hline Citric acid & 1.17 & not observed & not observed & not observed & not observed ${ }^{\mathrm{a}}$ \\
\hline Malonic acid & 1.33 & not observed & not observed & not observed & not observed ${ }^{\mathrm{a}}$ \\
\hline
\end{tabular}

${ }^{\text {a }}$ Data taken from You et al. (2013). All other data are from this study.

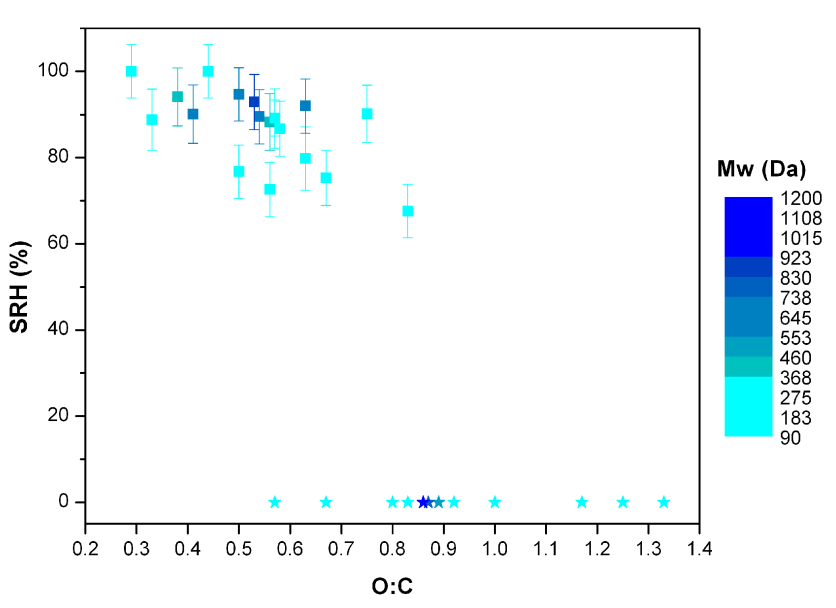

Figure 3. $\mathrm{SRH}$ as a function of $\mathrm{O}: \mathrm{C}$ of the organic species at $290 \pm 1 \mathrm{~K}$. The SRH results are from the current study and You et al. (2013) (see Table 3). The colors represent the molecular weight of the different organic species. Squares represent the SRH of particles in which liquid-liquid phase separation was observed. Bars for the squares are $95 \%$ confidence intervals considering $\sigma$ of multiple SRH measurements and the uncertainty from the calibration. Stars indicate liquid-liquid phase separation was not observed. $\mathrm{OIR}=2.0 \pm 0.1 \mathrm{in}$ all the experiments. and SRH and an associated low $p$ value $(\leq 0.06)$. A decrease in SRH with a decrease in temperature may be expected if there is a closed-loop miscibility gap and the measurements are probing the lower temperature region of the closed loop.

Based on our results, particles containing poly(propylene glycol) and ammonium sulfate had SRH values ranging from 87.7 to $94.1 \%$ as the temperature ranged from 244 to $290 \mathrm{~K}$. Solutions of water and poly(propylene glycol) show a lower critical solution temperature of approximately $50^{\circ} \mathrm{C}$ (Malcom and Rowlinson, 1957). A comparison between this result and our current results indicates that the lower critical solution temperature is decreased significantly when ammonium sulfate is added to mixtures of poly(propylene glycol) and water.

As mentioned in the Introduction, some mixtures of organic species and inorganic salts can become highly viscous at lower temperatures and low relative humidities, and at these low temperatures and relative humidities, liquid-liquid phase separation may be kinetically inhibited due to diffusion limitations. A possible reason that a stronger dependence on temperature was not observed in the studies discussed above may be because for the systems studied the particles either did not undergo liquid-liquid phase separation or the SRH was relatively high ( $>65 \% \mathrm{RH})$. For the cases where liquidliquid phase separation did not occur, an increase in viscosity from a decrease in temperature is not expected to change the 

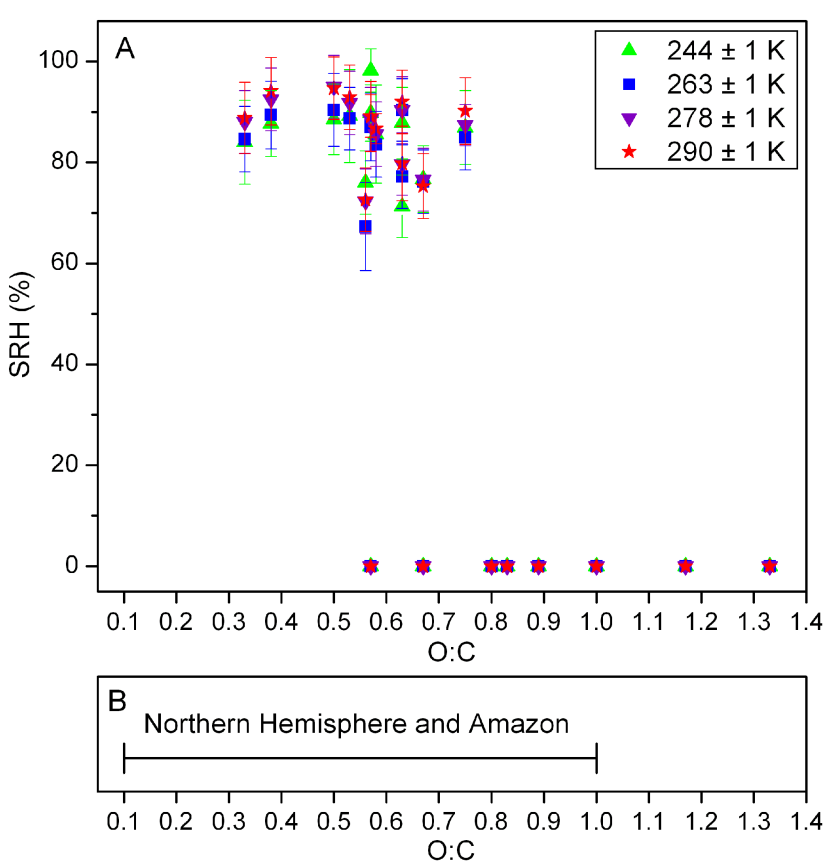

Figure 4. (a) SRH of mixed organic-ammonium sulfate particles as a function of $\mathrm{O}: \mathrm{C}$ measured at four different temperatures. Different symbols represent the different temperatures. Bars for the data are $95 \%$ confidence intervals considering $\sigma$ of multiple SRH measurements and the uncertainty from the calibration. Data at $\mathrm{SRH}=0 \%$ indicate liquid-liquid phase separation was not observed. Data plotted are summarized in Table 4. OIR $=2.0 \pm 0.1$ in all the experiments. (b) Range of the average $\mathrm{O}: \mathrm{C}$ of organic material in particles from measurements at many locations in the Northern Hemisphere and the Amazon.

results. For cases where the SRH was relatively high (> 65\% $\mathrm{RH})$, the water content in the particles was also likely relatively high. Since water is a plasticizer, high water contents can lead to low viscosities and high diffusion rates. In this case, unless the temperature is very low, liquid-liquid phase separation is not expected to be kinetically inhibited.

Although SRH does not appear to be a strong function of the temperature for the organic-ammonium sulfate particle types studied over the temperature range of 244 to $290 \mathrm{~K}$, SRH may be a strong function of temperature for these particles at temperatures lower than $244 \mathrm{~K}$ due to kinetic limitations or thermodynamic reasons. Additional studies of SRH at temperatures lower than $244 \mathrm{~K}$ are still needed for these particle types.

In Fig. 6, SRH as a function of temperature is plotted for particles containing $\alpha$,4-dihydroxy-3-methoxybenzeneacetic acid mixed with ammonium bisulfate. At $263 \pm 1 \mathrm{~K}$ and warmer, no strong dependence on temperature is observed, with an average SRH value of approximately $37.6 \%$. At $244 \mathrm{~K}$, however, liquid-liquid phase separation was not observed. A likely explanation for this drastic decrease in the SRH is likely kinetic inhabitation of the liquid-liquid phase

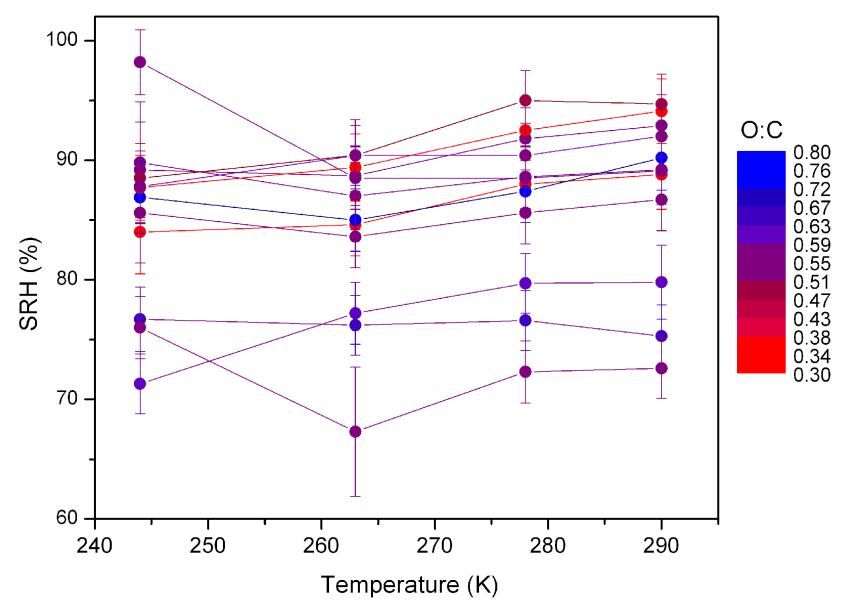

Figure 5. Summary of SRH as a function of temperature for 12 types of mixed organic-ammonium sulfate particles which underwent liquid-liquid phase separation. Data plotted were taken from Table 4. Bars for the data are $95 \%$ confidence intervals considering $\sigma$ of multiple SRH measurements and the uncertainty from the calibration. Colors represent the $\mathrm{O}: \mathrm{C}$ values of different organic species in the particles. OIR $=2.0 \pm 0.1$ in all the experiments.

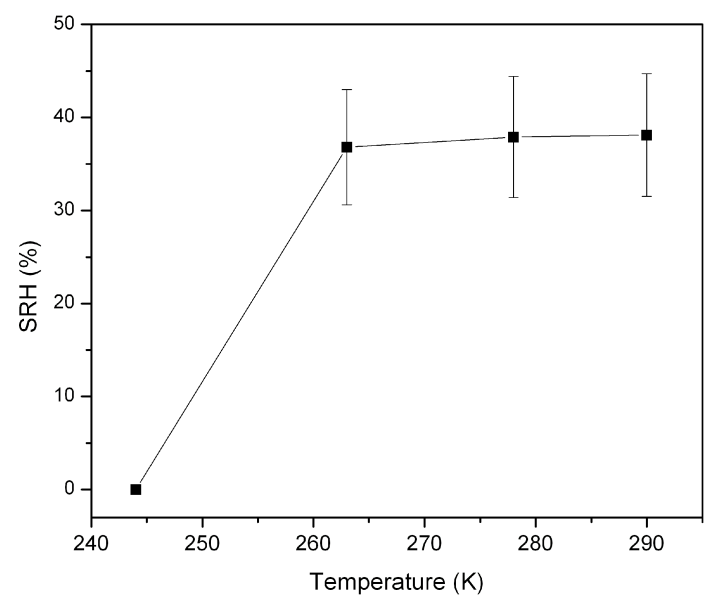

Figure 6. SRH as a function of temperature for particles containing $\alpha$,4-dihydroxy-3-methoxybenzeneacetic acid mixed with ammonium bisulfate. Bars for the data are $95 \%$ confidence intervals considering $\sigma$ of multiple SRH measurements and the uncertainty from the calibration. Data at $290 \pm 1 \mathrm{~K}$ were taken from You et al. (2013).

separation. Related previous research has shown that efflorescence is inhibited in particles containing organic species and inorganic salts at low temperatures and low relative humidities likely due to diffusion limitations (Bodsworth et al., 2010). The studies with particles containing ammonium bisulfate and $\alpha, 4$-dihydroxy-3-methoxybenzeneacetic acid suggest that a combination of low temperatures (e.g., $244 \mathrm{~K}$ ) and low relative humidities (e.g., approximately $38 \%$ 
RH) can lead to kinetic inhibition of liquid-liquid phase separation.

The average $\mathrm{O}: \mathrm{C}$ of organic material in atmospheric particles has been measured at many locations in the Northern Hemisphere and Amazon and has been shown to range from 0.1 to 1.0 (Chen et al., 2009; Aiken et al., 2008; DeCarlo et al., 2008; Jimenez et al., 2009; Hawkins et al., 2010; Heald et al., 2010; Ng et al., 2010; Takahama et al., 2011). This range of $\mathrm{O}: \mathrm{C}$ values is indicated in Fig. $4 \mathrm{~b}$. The range of average $\mathrm{O}: \mathrm{C}$ values measured in the atmosphere overlaps with the range of $\mathrm{O}: \mathrm{C}$ values where liquid-liquid phase separation was observed at temperatures ranging from 244 to $290 \mathrm{~K}$ (Fig. 4b). This overlap suggests that liquid-liquid phase separation is likely a common occurrence in the atmosphere over this temperature range. Particles that do not undergo liquid-liquid phase separation are also expected to be common based on a comparison between our data and the range of $\mathrm{O}: \mathrm{C}$ values found in the atmosphere.

\section{Conclusions}

The occurrence of liquid-liquid phase separation and SRH did not depend strongly on the molecular weight of the organic species at $290 \pm 1 \mathrm{~K}$, at least for the particle types studied. The occurrence of liquid-liquid phase separation and SRH also did not depend strongly on temperature over the range of 290-244 K for particles containing ammonium sulfate mixed with one organic species. The SRH varied by at most $9.7 \% \mathrm{RH}$ as the temperature varied from $290 \pm 1 \mathrm{~K}$ to $244 \pm 1 \mathrm{~K}$ for the particle types studied. The high SRH values (> 65\%) in these experiments may explain the lack of temperature dependence. Since water is a plasticizer, high relative humidities can lead to high water contents, low viscosities, and high diffusion rates. For these cases, unless the temperature is very low, liquid-liquid phase separation is not expected to be kinetically inhibited. The occurrence of liquidliquid phase separation and SRH did depend strongly on temperature over the range of 290-244 K for particles containing $\alpha$,4-dihydroxy-3-methoxybenzeneacetic acid mixed with ammonium bisulfate. For this particle type, a combination of low temperatures and low water content likely favored kinetic inhabitation of the liquid-liquid phase separation by slow diffusion rates in highly viscous particles.

The combined results suggest that liquid-liquid phase separation is likely a common occurrence in the atmospheric particles at $290-244 \mathrm{~K}$, although particles that do not undergo liquid-liquid phase separation are also likely common.

\section{The Supplement related to this article is available online at doi:10.5194/acp-15-1351-2015-supplement.}

Acknowledgements. This research was supported by the Natural Science and Engineering Research Council of Canada. We thank two anonymous referees for their very helpful suggestions.

Edited by: D. Topping

\section{References}

Aiken, A. C., Decarlo, P. F., Kroll, J. H., Worsnop, D. R., Huffman, J. A., Docherty, K. S., Ulbrich, I. M., Mohr, C., Kimmel, J. R., Sueper, D., Sun, Y., Zhang, Q., Trimborn, A., Northway, M., Ziemann, P. J., Canagaratna, M. R., Onasch, T. B., Alfarra, M. R., Prévôt, A. S. H., Dommen, J., Duplissy, J., Metzger, A., Baltensperger, U., and Jimenez, J. L.: O/C and OM/OC ratios of primary, secondary, and ambient organic aerosols with highresolution time-of-flight aerosol mass spectrometry, Environ. Sci. Technol., 42, 4478-4485, doi:10.1021/es703009q, 2008.

Anttila, T., Kiendler-Scharr, A., Tillmann, R., and Mentel, T. F.: On the reactive uptake of gaseous compounds by organic-coated aqueous aerosols: Theoretical analysis and application to the heterogeneous hydrolysis of $\mathrm{N}_{2} \mathrm{O}_{5}$, J. Phys. Chem. A, 110, 1043510443, doi:10.1021/jp062403c, 2006.

Anttila, T., Kiendler-Scharr, A., Mentel, T. F., and Tillmann, R.: Size dependent partitioning of organic material: evidence for the formation of organic coatings on aqueous aerosols, J. Atmos. Chem., 57, 215-237, doi:10.1007/s10874-007-9067-9, 2007.

Badger, C. L., George, I., Griffiths, P. T., Braban, C. F., Cox, R. A., and Abbatt, J. P. D.: Phase transitions and hygroscopic growth of aerosol particles containing humic acid and mixtures of humic acid and ammonium sulfate, Atmos. Chem. Phys., 6, 755-768, 2006, http://www.atmos-chem-phys.net/6/755/2006/.

Bertram, A. K., Martin, S. T., Hanna, S. J., Smith, M. L., Bodsworth, A., Chen, Q., Kuwata, M., Liu, A., You, Y., and Zorn, S. R.: Predicting the relative humidities of liquid-liquid phase separation, efflorescence, and deliquescence of mixed particles of ammonium sulfate, organic material, and water using the organic-to-sulfate mass ratio of the particle and the oxygen-tocarbon elemental ratio of the organic component, Atmos. Chem. Phys., 11, 10995-11006, doi:10.5194/acp-11-10995-2011, 2011.

Bodsworth, A., Zobrist, B., and Bertram, A. K.: Inhibition of efflorescence in mixed organic-inorganic particles at temperatures less than 250 K, Phys. Chem. Chem. Phys., 12, 12259-12266, doi:10.1039/c0cp00572j, 2010.

Braban, C. F. and Abbatt, J. P. D.: A study of the phase transition behavior of internally mixed ammonium sulfate - malonic acid aerosols, Atmos. Chem. Phys., 4, 1451-1459, doi:10.5194/acp4-1451-2004, 2004.

Brooks, S. D., Wise, M. E., Cushing, M., and Tolbert, M. A.: Deliquescence behavior of organic/ammonium sulfate aerosol, Geophys. Res. Lett., 29, 1917, doi:10.1029/2002GL014733, 2002.

Brooks, S. D., Garland, R. M., Wise, M. E., Prenni, A. J., Cushing, M., Hewitt, E., and Tolbert, M. A.: Phase changes in internally mixed maleic acid/ammonium sulfate aerosols, J. Geophys. Res., 108, 4478, doi:10.1029/2002jd003204, 2003. 
Buajarern, J., Mitchem, L., and Reid, J. P.: Characterizing multiphase Organic/Inorganic/Aqueous aerosol droplets, J. Phys. Chem. A, 111, 9054-9061, doi:10.1021/jp074366a, 2007.

Buzorius, G., Zelenyuk, A., Brechtel, F., and Imre, D.: Simultaneous determination of individual ambient particle size, hygroscopicity and composition, Geophys. Res. Lett., 29, 1974, doi:10.1029/2001GL014221, 2002.

Chan, M. N., and Chan, C. K.: Hygroscopic properties of two model humic-like substances and their mixtures with inorganics of atmospheric importance, Environ. Sci. Technol., 37, 5109-5115, doi:10.1021/es034272o, 2003.

Chang, E. I. and Pankow, J. F.: Prediction of activity coefficients in liquid aerosol particles containing organic compounds, dissolved inorganic salts, and water - Part 2: Consideration of phase separation effects by an X-UNIFAC model, Atmos. Environ., 40, 6422-6436, doi:10.1016/j.atmosenv.2006.04.031, 2006.

Chen, Q., Farmer, D. K., Schneider, J., Zorn, S. R., Heald, C. L., Karl, T. G., Guenther, A., Allan, J. D., Robinson, N., Coe, H., Kimmel, J. R., Pauliquevis, T., Borrmann, S., Pöschl, U., Andreae, M. O., Artaxo, P., Jimenez, J. L., and Martin, S. T.: Mass spectral characterization of submicron biogenic organic particles in the Amazon Basin, Geophys. Res. Lett., 36, L20806, doi:10.1029/2009GL039880, 2009.

Choi, M. Y. and Chan, C. K.: The effects of organic species on the hygroscopic behaviors of inorganic aerosols, Environ. Sci. Technol., 36, 2422-2428, doi:10.1021/es0113293, 2002.

Ciobanu, V. G., Marcolli, C., Krieger, U.K., Weers, U., and Peter, T.: Liquid-liquid phase separation in mixed organic/inorganic aerosol particles, J. Phys. Chem. A, 113, 10966-10978, doi:10.1021/jp905054d, 2009.

Clegg, S. L., Brimblecombe, P., and Wexler, A. S.: A thermodynamic model of the $\mathrm{H}^{+}-\mathrm{NH}_{4}^{+}-\mathrm{SO}_{4}^{2-}-\mathrm{NO}_{3}^{-}-\mathrm{H}_{2} \mathrm{O}$ at tropospheric temperatures, J. Phys. Chem. A, 102, 2137-2154, doi:10.1021/Jp973042r, 1998.

Clegg, S. L., Seinfeld, J. H., and Brimblecombe, P.: Thermodynamic modelling of aqueous aerosols containing electrolytes and dissolved organic compounds, J. Aerosol. Sci., 32, 713-738, doi:10.1016/S0021-8502(00)00105-1, 2001.

Cosman, L. M., and Bertram, A. K.: Reactive uptake of $\mathrm{N}_{2} \mathrm{O}_{5}$ on aqueous $\mathrm{H}_{2} \mathrm{SO}_{4}$ solutions coated with 1-component and 2component monolayers, J. Phys. Chem. A, 112, 4625-4635, doi:10.1021/Jp8005469, 2008.

Day, D. A., Takahama, S., Gilardoni, S., and Russell, L. M.: Organic composition of single and submicron particles in different regions of western North America and the eastern Pacific during INTEX-B 2006, Atmos. Chem. Phys., 9, 5433-5446, doi:10.5194/acp-9-5433-2009, 2009.

DeCarlo, P. F., Dunlea, E. J., Kimmel, J. R., Aiken, A. C., Sueper, D., Crounse, J., Wennberg, P. O., Emmons, L., Shinozuka, Y., Clarke, A., Zhou, J., Tomlinson, J., Collins, D. R., Knapp, D., Weinheimer, A. J., Montzka, D. D., Campos, T., and Jimenez, J. L.: Fast airborne aerosol size and chemistry measurements above Mexico City and Central Mexico during the MILAGRO campaign, Atmos. Chem. Phys., 8, 4027-4048, doi:10.5194/acp-8-4027-2008, 2008.

Decesari, S., Fuzzi, S., Facchini, M. C., Mircea, M., Emblico, L., Cavalli, F., Maenhaut, W., Chi, X., Schkolnik, G., Falkovich, A., Rudich, Y., Claeys, M., Pashynska, V., Vas, G., Kourtchev, I., Vermeylen, R., Hoffer, A., Andreae, M. O., Tagliavini, E.,
Moretti, F., and Artaxo, P.: Characterization of the organic composition of aerosols from Rondônia, Brazil, during the LBASMOCC 2002 experiment and its representation through model compounds, Atmos. Chem. Phys., 6, 375-402, doi:10.5194/acp6-375-2006, 2006.

Dibb, J. E., Talbot, R. W., Klemm, K. I., Gregory, G. L., Singh, H. B., Bradshaw, J. D., and Sandholm, S. T.: Asian influence over the western North Pacific during the fall season: Inferences from lead 210, soluble ionic species and ozone, J. Geophys. Res., 101, 1779-1792, doi:10.1029/94JD03117, 1996.

Dibb, J. E., Talbot, R. W., and Scheuer, E. M.: Composition and distribution of aerosols over the North Atlantic during the Subsonic Assessment Ozone and Nitrogen Oxide Experiment (SONEX), J. Geophys. Res., 105, 3709-3717, doi:10.1029/1999JD900424, 2000.

Drozd, G. T., Woo, J. L., and McNeill, V. F.: Self-limited uptake of $\alpha$-pinene oxide to acidic aerosol: the effects of liquid-liquid phase separation and implications for the formation of secondary organic aerosol and organosulfates from epoxides, Atmos. Chem. Phys., 13, 8255-8263, doi:10.5194/acp-13-8255-2013, 2013.

Erdakos, G. B., Chang, E. I., Pankow, J. F., and Seinfeld, J. H.: Prediction of activity coefficients in liquid aerosol particles containing organic compounds, dissolved inorganic salts, and water - Part 3: Organic compounds, water, and ionic constituents by consideration of short-, mid-, and long-range effects using X-UNIFAC.3, Atmos. Environ., 40, 6437-6452, doi:10.1016/j.atmosenv.2006.04.001, 2006.

Escoreia, E. N., Sjostedt, S. J., and Abbatt, J. P. D.: Kinetics of $\mathrm{N}_{2} \mathrm{O}_{5}$ hydrolysis on secondary organic aerosol and mixed ammonium bisulfate-secondary organic aerosol particles, J. Phys. Chem. A, 114, 13113-13121, doi:10.1021/jp107721v, 2010.

Faucher, J. A., Koleske, J. V., Santee, E. R., Stratta, J. J., Wilson, C. W.: Glass transitions of ethylene oxide polymers, J. Appl. Phys. 37, 3962-3964, 1966.

Finlayson-Pitts, B. J. and Pitts, J. N.: Tropospheric air pollution: Ozone, airborne toxics, polycyclic aromatic hydrocarbons, and particles, Science, 276, 1045-1052, doi:10.1126/science.276.5315.1045, 1997.

Finlayson-Pitts, B. J. and Pitts, J. N.: Chemistry of the upper and lower atmosphere: theory, experiments and applications, Academic Press, San Diego, California, London, pp. 969, 2000.

Folkers, M., Mentel, T. F., and Wahner, A.: Influence of an organic coating on the reactivity of aqueous aerosols probed by the heterogeneous hydrolysis of $\mathrm{N}_{2} \mathrm{O}_{5}$, Geophys. Res. Lett., 30, 1644, doi:10.1029/2003GL017168, 2003.

Fu, P. Q., Kawamura, K., and Miura, K.: Molecular characterization of marine organic aerosols collected during a round-the-world cruise, J. Geophys. Res., 116, D13302, doi:10.1029/2011jd015604, 2011.

Fuzzi, S., Decesari, S., Facchini, M. C., Matta, E., Mircea, M., and Tagliavini, E.: A simplified model of the water soluble organic component of atmospheric aerosols, Geophys. Res. Lett., 28, 4079-4082, doi:10.1029/2001g1013418, 2001.

Gao, S., Keywood, M., Ng, N. L., Surratt, J., Varutbamgkul, V., Bahreini, R., Flagan, R. C., and Seinfeld, J. H.: Low-molecularweight and oligomeric components in secondary organic aerosol from the ozonolysis of cycloalkenes and $\alpha$-pinene, J. Phys. Chem. A, 108, 10147-10164, doi:10.1021/jp047466e, 2004. 
Gaston, C. J., Thornton, J. A., and Ng, N. L.: Reactive uptake of $\mathrm{N}_{2} \mathrm{O}_{5}$ to internally mixed inorganic and organic particles: the role of organic carbon oxidation state and inferred organic phase separations, Atmos. Chem. Phys., 14, 5693-5707, doi:10.5194/acp-14-5693-2014, 2014.

Gilardoni, S., Liu, S., Takahama, S., Russell, L. M., Allan, J. D., Steinbrecher, R., Jimenez, J. L., De Carlo, P. F., Dunlea, E. J., and Baumgardner, D.: Characterization of organic ambient aerosol during MIRAGE 2006 on three platforms, Atmos. Chem. Phys., 9, 5417-5432, doi:10.5194/acp-9-5417-2009, 2009.

Goldstein, A. H. and Galbally, I. E.: Known and unexplored organic constituents in the earth's atmosphere, Environ, Sci, Technol., 41, 1514-1521, doi:10.1021/es072476p, 2007.

Greener, J., Gillmor, J. R., and Daly, R. C.: Melt rheology of a class of polyester ionomers, Marcromolecules, 26, 6416-6424, doi:10.1021/ma00076a018, 1993.

Hallquist, M., Wenger, J. C., Baltensperger, U., Rudich, Y., Simpson, D., Claeys, M., Dommen, J., Donahue, N. M., George, C., Goldstein, A. H., Hamilton, J. F., Herrmann, H., Hoffmann, T., Iinuma, Y., Jang, M., Jenkin, M. E., Jimenez, J. L., KiendlerScharr, A., Maenhaut, W., McFiggans, G., Mentel, Th. F., Monod, A., Prévôt, A. S. H., Seinfeld, J. H., Surratt, J. D., Szmigielski, R., and Wildt, J.: The formation, properties and impact of secondary organic aerosol: current and emerging issues, Atmos. Chem. Phys., 9, 5155-5236, doi:10.5194/acp-9-51552009, 2009.

Hamilton, J. F., Webb, P. J., Lewis, A. C., Hopkins, J. R., Smith, S., and Davy, P.: Partially oxidised organic components in urban aerosol using GCXGC-TOF/MS, Atmos. Chem. Phys., 4, 12791290, doi:10.5194/acp-4-1279-2004, 2004.

Hawkins, L. N., Russell, L. M., Covert, D. S., Quinn, P. K., and Bates, T. S.: Carboxylic acids, sulfates, and organosulfates in processed continental organic aerosol over the southeast Pacific Ocean during VOCALS-REx 2008, J. Geophys. Res., 115, D13201, doi:10.1029/2009jd013276, 2010.

Heald, C. L., Kroll, J. H., Jimenez, J. L., Docherty, K. S., DeCarlo, P. F., Aiken, A. C., Chen, Q., Martin, S. T., Farmer, D. K., and Artaxo, P.: A simplified description of the evolution of organic aerosol composition in the atmosphere, Geophys. Res. Lett., 37, L08803, doi:10.1029/2010g1042737, 2010.

Huebert, B. J., Howell, S. G., Zhuang, L., Heath, J. A., Litchy, M. R., Wylie, D. J., Kreidler-Moss, J. L., Coppicus, S., and Pfeiffer, J. E.: Filter and impactor measurements of anions and cations during the First Aerosol Characterization Experiment (ACE 1), J. Geophys. Res., 103, 16493-16509, doi:10.1029/98jd00770, 1998.

Jimenez, J. L., Canagaratna, M. R., Donahue, N. M., Prevot, A. S. H., Zhang, Q., Kroll, J. H., DeCarlo, P. F., Allan, J. D., Coe, H., Ng, N. L., Aiken, A. C., Docherty, K. S., Ulbrich, I. M., Grieshop, A. P., Robinson, A. L., Duplissy, J., Smith, J. D., Wilson, K. R., Lanz, V. A., Hueglin, C., Sun, Y. L., Tian, J., Laaksonen, A., Raatikainen, T., Rautiainen, J., Vaattovaara, P., Ehn, M., Kulmala, M., Tomlinson, J. M., Collins, D. R., Cubison, M. J., Dunlea, E. J., Huffman, J. A., Onasch, T. B., Alfarra, M. R., Williams, P. I., Bower, K., Kondo, Y., Schneider, J., Drewnick, F., Borrmann, S., Weimer, S., Demerjian, K., Salcedo, D., Cottrell, L., Griffin, R., Takami, A., Miyoshi, T., Hatakeyama, S., Shimono, A., Sun, J. Y., Zhang, Y. M., Dzepina, K., Kimmel, J. R., Sueper, D., Jayne, J. T., Herndon, S. C., Trim- born, A. M., Williams, L. R., Wood, E. C., Middlebrook, A. M., Kolb, C. E., Baltensperger, U., and Worsnop, D. R.: Evolution of organic aerosols in the atmosphere, Science, 326, 1525-1529, doi:10.1126/science.1180353, 2009.

Kalberer, M., Paulsen, D., Sax, M., Steinbrecher, M., Dommen, J., Prevot, A. S. H., Fisseha, R., Weingartner, E., Frankevich, V., Zenobi, R., and Baltensperger, U.: Identification of ploymers as major components of atmospheric organic aerosols, Science, 303, 1659-1662, doi:10.1126/science.1092185, 2004.

Kidd, C., Perraud, V., Wingen, L. M., and Finlayson-Pitts, B. J.: Integrating phase and composition of secondary organic aerosol from the ozonolysis of $\alpha$-pinene, P. Natl. Acad. Sci. USA, 111, 7552-7557, doi:10.1073/pnas.1322558111, 2014.

Koop, T., Kapilashrami, A., Molina, L. T., and Molina, M. J.: Phase transitions of sea-salt/water mixtures at low temperatures: Implications for ozone chemistry in the polar marine boundary layer, J. Geophys. Res., 105, 26393-26402, doi:10.1029/2000jd900413, 2000.

Koop, T., Bookhold, J., Shiraiwa, M., and Pöschl, U.: Glass transition and phase state of organic compounds: dependency on molecular properties and implications for secondary organic aerosols in the atmosphere, Phys. Chem. Chem. Phys., 13, 19238-19255, doi:10.1039/C1cp22617g, 2011.

Krieger, U.K., Marcolli, C., and Reid, J. P.: Exploring the complexity of aerosol particle properties and processes using single particle techniques, Chem. Soc. Rev., 41, 6631-6662, doi:10.1039/C2cs35082c, 2012.

Kwamena, N. O. A., Buajarern, J., and Reid, J. P.: Equilibrium Morphology of Mixed Organic/Inorganic/Aqueous Aerosol Droplets: Investigating the Effect of Relative Humidity and Surfactants, J. Phys. Chem. A, 114, 5787-5795, doi:10.1021/jp1003648, 2010.

Lee, Y.-N., Weber, R., Ma, Y., Orsini, D., Maxwell-Meier, K., Blake, D., Meinardi, S., Sachse, G., Harward, C., Chen, T. Y., Thornton, D., Tu, F.-H., and Bandy, A.: Airborne measurement of inorganic ionic components of fine aerosol particles using the particle-into-liquid sampler coupled to ion chromatography technique during ACE-Asia and TRACE-P, J. Geophys. Res., 108, 8646, doi:10.1029/2002JD003265, 2003.

Levine, I. N.: Physical Chemistry, 6th edition. McGraw-Hill, New York, 2009

Ling, T. Y. and Chan, C. K.: Partical crystallization and deliquescence of particles containing ammonium sulfate and dicarboxylic acids, J. Geophys. Res., 113, D14205, doi:10.1029/2008JD009779, 2008.

Liu, S., Takahama, S., Russell, L. M., Gilardoni, S., and Baumgardner, D.: Oxygenated organic functional groups and their sources in single and submicron organic particles in MILAGRO 2006 campaign, Atmos. Chem. Phys., 9, 6849-6863, doi:10.5194/acp9-6849-2009, 2009.

Malcolm, G. N. and Rowlinson, J. S.: The Thermodynamic Properties of Aqueous Solutions of Polyethylene Glycol, Polypropylene Glycol and Dioxane, T. Faraday Soc., 53, 921-931, doi:10.1039/Tf9575300921, 1957.

Marcolli, C., and Krieger, U.K.: Phase changes during hygroscopic cycles of mixed organic/inorganic model systems of tropospheric aerosols, J. Phys. Chem. A, 110, 1881-1893, doi:10.1021/jp0556759, 2006.

Martin, S. T.: Phase transitions of aqueous atmospheric particles, Chem. Rev., 100, 3403-3453, doi:10.1021/cr990034t, 2000. 
McNeill, V. F., Patterson, J., Wolfe, G. M., and Thornton, J. A.: The effect of varying levels of surfactant on the reactive uptake of $\mathrm{N}_{2} \mathrm{O}_{5}$ to aqueous aerosol, Atmos. Chem. Phys., 6, 1635-1644, doi:10.5194/acp-6-1635-2006, 2006.

Middlebrook, A. M., Murphy, D. M., and Thomson, D. S.: Observations of organic material in individual marine particles at Cape Grim during the First Aerosol Characterization Experiment (ACE 1), J. Geophys. Res., 103, 16475-16483, doi:10.1029/97jd03719, 1998.

Mikhailov, E., Vlasenko, S., Martin, S. T., Koop, T., and Pöschl, U.: Amorphous and crystalline aerosol particles interacting with water vapor: conceptual framework and experimental evidence for restructuring, phase transitions and kinetic limitations, Atmos. Chem. Phys., 9, 9491-9522, 2009,

http://www.atmos-chem-phys.net/9/9491/2009/.

Murphy, D. M. and Thomson, D. S.: Chemical composition of single aerosol particles at Idaho Hill: Negative ion measurements, J. Geophys. Res., 102, 6353-6368, doi:10.1029/96jd00859, 1997.

Murphy, D. M., Thomson, D. S., and Mahoney, T. M. J.: In situ measurements of organics, meteoritic material, mercury, and other elements in aerosols at 5 to 19 kilometers, Science, 282, 16641669, doi:10.1126/science.282.5394.1664, 1998.

Murphy, D. M.: Something in the air, Science, 307, 1888-1890, doi:10.1126/science.1108160, 2005.

Murphy, D. M., Cziczo, D. J., Froyd, K. D., Hudson, P. K., Matthew, B. M., Middlebrook, A. M., Peltier, R. E., Sullivan, A., Thomson, D. S., and Weber, R. J.: Single-particle mass spectrometry of tropospheric aerosol particles, J. Geophys. Res., 111, D23S32, doi:10.1029/2006JD007340, 2006.

Murray, B. J.: Inhibition of ice crystallisation in highly viscous aqueous organic acid droplets, Atmos. Chem. Phys., 8, 54235433, 2008, http://www.atmos-chem-phys.net/8/5423/2008/.

Ng, N. L., Canagaratna, M. R., Zhang, Q., Jimenez, J. L., Tian, J., Ulbrich, I. M., Kroll, J. H., Docherty, K. S., Chhabra, P. S., Bahreini, R., Murphy, S. M., Seinfeld, J. H., Hildebrandt, L., Donahue, N. M., DeCarlo, P. F., Lanz, V. A., Prévôt, A. S. H., Dinar, E., Rudich, Y., and Worsnop, D. R.: Organic aerosol components observed in Northern Hemispheric datasets from Aerosol Mass Spectrometry, Atmos. Chem. Phys., 10, 46254641, doi:10.5194/acp-10-4625-2010, 2010.

Nguyen, T. B., Bateman, A. P., Bones, D. L., Nizkorodov, S. A., Laskin, J., and Laskin, A.: High-resolution mass spectrometry analysis of secondary organic aerosol generated by ozonolysis of isoprene, Atmos. Environ., 44, 1032-1042, doi: 10.1016/j.atmosenv.2009.12.019, 2010.

Pankow, J. F.: Gas/particle partitioning of neutral and ionizing compounds to single and multi-phase aerosol particles, 1. Unified modeling framework, Atmos. Environ., 37, 3323-3333, doi:10.1016/S1352-2310(03)00346-7, 2003.

Pant, A., Fok, A., Parsons, M. T., Mak, J., and Bertram, A. K.: Deliquescence and crystallization of ammonium sulfate-glutaric acid and sodium chloride-glutaric acid particles, Geophys. Res. Lett., 31, L12111, doi:10.1029/2004GL020025, 2004.

Pant, A., Parsons, M. T., and Bertram, A. K.: Crystallization of aqueous ammonium sulfate particles internally mixed with soot and kaolinite: Crystallization relative humidities and nucleation rates, J. Phys. Chem. A, 110, 8701-8709, doi:10.1021/jp060985s, 2006.
Park, S. C., Burden, D. K., and Nathanson, G. M.: The inhibition of $\mathrm{N}_{2} \mathrm{O}_{5}$ hydrolysis in sulfuric acid by 1-butanol and 1hexanol surfactant coatings, J. Phys. Chem. A, 111, 2921-2929, doi:10.1021/Jp068228h, 2007.

Parsons, M. T., Knopf, D. A., and Bertram, A. K.: Deliquescence and crystallization of ammonium sulfate particles internally mixed with water-soluble organic compounds, J. Phys. Chem. A, 108, 11600-11608, doi:10.1021/jp0462862, 2004a.

Parsons, M. T., Mak, J., Lipetz, S. R., and Bertram, A. K.: Deliquescence of malonic, succinic, glutaric, and adipic acid particles, J. Geophys. Res., 109, D06212, doi:10.1029/2003JD004075, 2004b.

Parsons, M. T., Riffell, J. L., and Bertram, A. K.: Crystallization of aqueous inorganic-malonic acid particles: Nucleation rates, dependence on size, and dependence on the ammonium-to-sulfate, J. Phys. Chem. A, 110, 8108-8115, doi:10.1021/jp057074n, 2006.

Pöhlker, C., Wiedemann, K. T., Sinha, B., Shiraiwa, M., Gunthe, S. S., Smith, M., Su, H., Artaxo, P., Chen, Q., Cheng, Y. F., Elbert, W., Gilles, M.K., Kilcoyne, A. L. D., Moffet, R. C., Weigand, M., Martin, S. T., Pöschl, U., and Andreae, M. O.: Biogenic Potassium Salt Particles as Seeds for Secondary Organic Aerosol in the Amazon, Science, 337, 10751078, doi:10.1126/science.1223264, 2012.

Power, R. M., Simpson, S. H., Reid, J. P., and Hudson, A. J.: The transition from liquid to solid-like behaviour in ultrahigh viscosity aerosol particles, Chem. Sci., 4, 2597-2604, doi:10.1039/C3sc50682g, 2013.

Pratt, K. A., and Prather, K. A.: Aircraft measurements of vertical profiles of aerosol mixing states, J. Geophys. Res., 115, D11305, doi:10.1029/2009JD013150, 2010.

Prisle, N. L., Engelhart, G. J., Bilde, M., and Donahue, N. M.: Humidity influence on gas-particle phase partitioning of $\alpha$-pinene + $\mathrm{O}_{3}$ secondary organic aerosol, Geophys. Res. Lett., 37, L01802, doi:10.1029/2009GL041402, 2010.

Reid, J. P., Dennis-Smither, B. J., Kwamena, N. O. A., Miles, R. E. H., Hanford, K. L., and Homer, C. J.: The morphology of aerosol particles consisting of hydrophobic and hydrophilic phases: hydrocarbons, alcohols and fatty acids as the hydrophobic component, Phys. Chem. Chem. Phys., 13, 15559-15572, doi: 10.1039/c1cp21510h, 2011.

Renbaum-Wolff, L., Grayson, J. W., Bateman, A. P., Kuwata, M., Sellier, M., Murray, B. J., Shilling, J. E., Martin, S. T., and Bertram, A. K.: Viscosity of $\alpha$-pinene secondary organic material and implications for particle growth and reactivity, P. Natl. Acad. Sci. USA, 110, 8014-8019, doi:10.1073/pnas.1219548110, 2013.

Rogge, W. F., Mazurek, M. A., Hildemann, L. M., Cass, G. R., and Simoneit, B. R. T.: Quantification of urban organic aerosols at a molecular-level: identification, abundance and seasonal-variation, Atmos. Environ. A-Gen, 27, 1309-1330, doi:10.1016/0960-1686(93)90257-Y, 1993.

Russell, L. M., Takahama, S., Liu, S., Hawkins, L. N., Covert, D. S., Quinn, P. K., and Bates, T. S.: Oxygenated fraction and mass of organic aerosol from direct emission and atmospheric processing measured on the R/V Ronald Brown during TEXAQS/GoMACCS 2006, J. Geophys. Res., 114, D00F05, doi:10.1029/2008JD011275, 2009. 
Russell, L. M., Bahadur, R., and Ziemann, P. J.: Identifying organic aerosol sources by comparing functional group composition in chamber and atmospheric particles, P. Natl. Acad. Sci. USA, 108, 3516-3521, doi:10.1073/pnas.1006461108, 2011.

Salcedo, D.: Equilibrium phase diagrams of aqueous mixtures of malonic acid and sulfate/ammonium salts, J. Phys. Chem. A, 110, 12158-12165, doi:10.1021/jp063850v, 2006.

Saukko, E., Lambe, A. T., Massoli, P., Koop, T., Wright, J. P., Croasdale, D. R., Pedernera, D. A., Onasch, T. B., Laaksonen, A., Davidovits, P., Worsnop, D. R., and Virtanen, A.: Humiditydependent phase state of SOA particles from biogenic and anthropogenic precursors, Atmos. Chem. Phys., 12, 7517-7529, doi:10.5194/acp-12-7517-2012, 2012.

Saxena, P. and Hildemann, L. M.: Water-soluble organics in atmospheric particles: A critical review of the literature and application of thermodynamics to identify candidate compounds, J. Atmos. Chem., 24, 57-109, doi:10.1007/BF00053823, 1996.

Schill, G. P. and Tolbert, M. A.: Heterogeneous ice nucleation on phase-separated organic-sulfate particles: effect of liquid vs. glassy coatings, Atmos. Chem. Phys., 13, 4681-4695, doi:10.5194/acp-13-4681-2013, 2013.

Seinfeld, J. H., Erdakos, G. B., Asher, W. E., and Pankow, J. F.: Modeling the formation of secondary organic aerosol (SOA). 2 . The predicted effects of relative humidity on aerosol formation in the $\alpha$-pinene-, $\beta$-pinene-, sabinene-, $\Delta^{3}$-Carene-, and cyclohexene-ozone systems, Environ. Sci. Technol., 35, 18061817, doi:10.1021/es001765+, 2001.

Seinfeld, J. H. and Pandis, S. N.: Atmospheric Chemistry and Physics: From Air pollution to Climate Change, 2nd ed., WileyInterscience, Hoboken, New Jersey, 2006.

Shiraiwa, M., Zuend, A., Bertram, A. K., and Seinfeld, J. H.: Gasparticle partitioning of atmospheric aerosols: interplay of physical state, non-ideal mixing and morphology, Phys. Chem. Chem. Phys., 15, 11441-11453, doi:10.1039/C3cp51595h, 2013.

Slade, L. and Levine, H.: Water and the glass-transition - dependence of the glass-transition on composition and chemical-structure -special implications for flour functionality in cookie baking, J. Food Eng., 22, 143-188, doi:10.1016/02608774(94)90029-9, 1994.

Smith, M. L., Kuwata, M., and Martin, S. T.: Secondary organic material produced by the dark ozonolysis of $\alpha$ pinene minimally affects the deliquescence and efflorescence of ammonium sulfate, Aerosol Sci. Technol., 45, 244-261, doi:10.1080/02786826.2010.532178, 2011.

Smith, M. L., Bertram, A. K., and Martin, S. T.: Deliquescence, efflorescence, and phase miscibility of mixed particles of ammonium sulfate and isoprene-derived secondary organic material, Atmos. Chem. Phys., 12, 9613-9628, doi:10.5194/acp-12-96132012, 2012.

Song, M., Marcolli, C., Krieger, U. K., Zuend, A., and Peter, T.: Liquid-liquid phase separation and morphology of internally mixed dicarboxylic acids/ammonium sulfate/water particles, Atmos. Chem. Phys., 12, 2691-2712, doi:10.5194/acp-12-26912012, 2012a.

Song, M., Marcolli, C., Krieger, U. K., Zuend, A., and Peter, T.: Liquid-liquid phase separation in aerosol particles: Dependence on $\mathrm{O}: \mathrm{C}$, organic functionalities, and compositional complexity, Geophys. Res. Lett., 39, L19801, doi:10.1029/2012GL052807, 2012 b.
Song, M., Marcolli, C., Krieger, U. K., Lienhard, D. M., and Peter, T.: Morphologies of mixed orgnaic/inorganic/aqueous aerosol droplets, Faraday Discuss., 165, 289-316, doi:10.1039/C3FD00049D, 2013.

Takahama, S., Schwartz, R. E., Russell, L. M., Macdonald, A. M., Sharma, A., and Leaitch, W. R.: Organic functional groups in aerosol particles from burning and non-burning forest emissions at high-elevation mountain site, Atmos. Chem. Phys., 11, 63676386, doi:10.5194/acp-11-6367-2011, 2011.

Talbot, R. W., Dibb, J. E., and Loomis, M. B.: Influence of vertical transport on free tropospheric aerosols over the central USA in springtime, Geophys. Res. Lett., 25, 1367-1370, doi:10.1029/98GL00184, 1998.

Thornton, J. A. and Abbatt, J. P. D.: $\mathrm{N}_{2} \mathrm{O}_{5}$ reaction on submicron sea salt aerosol: Kinetics, products, and the effect of surface active organics, J. Phys. Chem. A, 109, 10004-10012, doi:10.1021/Jp054183t, 2005.

Tolocka, M. P., Jang, M., Ginter, J. M., Cox, R. J., Kamens, R. M., and Johnston, M. V.: Formation of oligomers in secondary organic aerosol, Environ, Sci, Technol., 38, 1428-1434, doi:10.1021/es035030r, 2004.

Tolocka, M. P., Lake, D. A., Johnston, M. V., and Wexler, A. S.: Size-resolved fine and ultrafine particle composition in Baltimore, Maryland, J. Geophys. Res., 110, D07S04, doi:10.1029/2004JD004573, 2005.

Tong, H. J., Reid, J. P., Bones, D. L., Luo, B. P., and Krieger, U. K.: Measurements of the timescales for the mass transfer of water in glassy aerosol at low relative humidity and ambient temperature, Atmos. Chem. Phys., 11, 4739-4754, doi:10.5194/acp-11-47392011, 2011.

Treuel, L., Pederzani, S., and Zellner, R.: Deliquescence behaviour and crystallisation of ternary ammonium sulfate/dicarboxylic acid/water aerosols, Phys. Chem. Chem. Phys., 11, 7976-7984, doi:10.1039/b905007h, 2009.

Veghte, D. P., Altaf, M. B., and Freedman, M. A.: Size Dependence of the Structure of Organic Aerosol, J. Am. Chem. Soc., 135, 16046-16049, doi:10.1021/Ja408903g, 2013.

Veghte, D. P., Bittner, D. R., and Freedman, M. A.: CryoTransmission Electron Microscopy Imaging of the Morphology of Submicrometer Aerosol Containing Organic Acids and Ammonium Sulfate, Anal. Chem., 86, 2436-2442, doi:10.1021/ac403279f, 2014.

Wise, M. E., Surratt, J. D., Curtis, D. B., Shilling, J. E., and Tolbert, M. A.: Hygroscopic growth of ammonium sulfate/dicarboxylic acids, J. Geophys. Res., 108, 4638, doi:10.1029/2003JD003775, 2003.

You, Y., Renbaum-Wolff, L., Carreras-Sospedra, M., Hanna, S. J., Hiranuma, N., Kamal, S., Smith, M. L., Zhang, X. L., Weber, R. J., Shilling, J. E., Dabdub, D., Martin, S. T., and Bertram, A. K.: Images reveal that atmospheric particles can undergo liquidliquid phase separations, P. Natl. Acad. Sci. USA, 109, 13188 13193, doi:10.1073/pnas.1206414109, 2012.

You, Y., Renbaum-Wolff, L., and Bertram, A. K.: Liquid-liquid phase separation in particles containing organics mixed with ammonium sulfate, ammonium bisulfate, ammonium nitrate or sodium chloride, Atmos. Chem. Phys., 13, 11723-11734, doi:10.5194/acp-13-11723-2013, 2013.

You, Y., Smith, M. L., Song, M., Martin, S. T., and Bertram, A. K.: Liquid-liquid phase separation in atmospherically relevant parti- 
cles consisting of organic species and inorganic salts, Int. Rev. Phys. Chem., 33, 43-77, doi:10.1080/0144235X.2014.890786, 2014.

Zobrist, B., Marcolli, C., Pedernera, D. A., and Koop, T.: Do atmospheric aerosols form glasses?, Atmos. Chem. Phys., 8, 52215244, 2008,

http://www.atmos-chem-phys.net/8/5221/2008/.

Zobrist, B., Soonsin, V., Luo, B. P., Krieger, U. K., Marcolli, C., Peter, T., and Koop, T.: Ultra-slow water diffusion in aqueous sucrose glasses, Phys. Chem. Chem. Phys., 13, 3514-3526, doi:10.1039/c0cp01273d, 2011.

Zuend, A., Marcolli, C., Luo, B. P., and Peter, T.: A thermodynamic model of mixed organic-inorganic aerosols to predict activity coefficients, Atmos. Chem. Phys., 8, 4559-4593, doi:10.5194/acp8-4559-2008, 2008.

Zuend, A., Marcolli, C., Peter, T., and Seinfeld, J. H.: Computation of liquid-liquid equilibria and phase stabilities: implications for RH-dependent gas/particle partitioning of organic-inorganic aerosols, Atmos. Chem. Phys., 10, 7795-7820, doi:10.5194/acp10-7795-2010, 2010.
Zuend, A., Marcolli, C., Booth, A. M., Lienhard, D. M., Soonsin, V., Krieger, U. K., Topping, D. O., McFiggans, G., Peter, T., and Seinfeld, J. H.: New and extended parameterization of the thermodynamic model AIOMFAC: calculation of activity coefficients for organic-inorganic mixtures containing carboxyl, hydroxyl, carbonyl, ether, ester, alkenyl, alkyl, and aromatic functional groups, Atmos. Chem. Phys., 11, 9155-9206, doi:10.5194/acp11-9155-2011, 2011.

Zuend, A. and Seinfeld, J. H.: Modeling the gas-particle partitioning of secondary organic aerosol: the importance of liquidliquid phase separation, Atmos. Chem. Phys., 12, 3857-3882, doi:10.5194/acp-12-3857-2012, 2012.

Zuend, A. and Seinfeld, J. H.: A practical method for the calculation of liquid-liquid equilibria in multicomponent organic-waterelectrolyte systems using physicochemical constraints, Fluid Phase Equilib., 337, 201-213, doi:10.1016/j.fluid.2012.09.034, 2013. 